\title{
Working
}

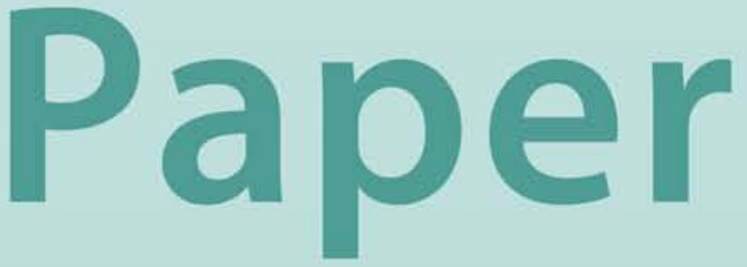




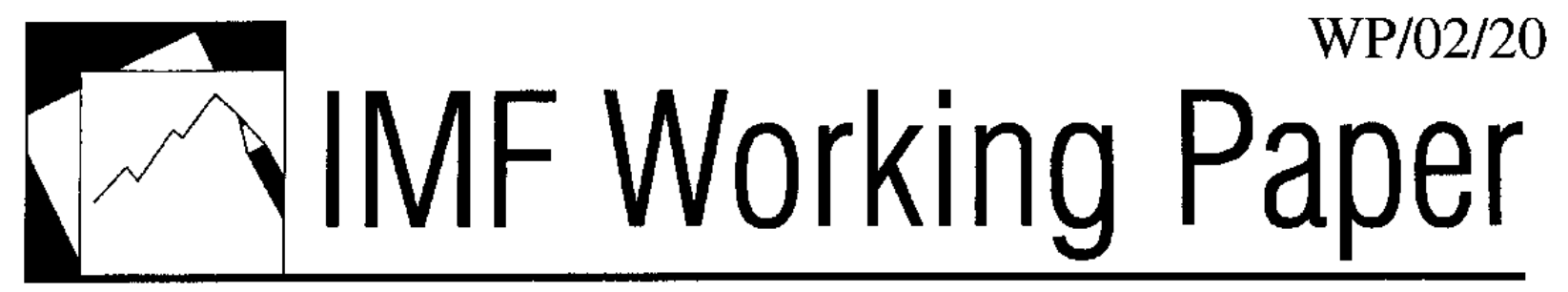

Lending Booms, Real Estate Bubbles and The Asian Crisis

Charles Collyns and Abdelhak Senhadji 


\title{
IMF Working Paper
}

Asia and Pacific Department

\section{Lending Booms, Real Estate Bubbles, and The Asian Crisis}

\author{
Prepared by Charles Collyns and Abdelhak Senhadji ${ }^{1}$
}

January 2002

\begin{abstract}
The views expressed in this Working Paper are those of the author(s) and do not necessarily represent those of the IMF or IMF policy. Working Papers describe research in progress by the author(s) and are published to elicit comments and to further debate.
\end{abstract}

This paper examines the link between lending booms, asset price cycles, and financial crises across East Asian countries. Both theoretical arguments and empirical evidence support a strong relationship between bank lending and asset price inflation, especially in the real estate market. While asset price bubbles were present in most Asian countries during the 1990s, their subsequent bust has affected countries quite differently. Some countries underwent severe exchange and financial crises, while others were able to weather the storm with much less damage. This experience underlines the importance of a strong bank regulatory system.

JEL Classification Numbers:G12, G21

Keywords: Lending Booms, Real Estate Bubbles, Asia Crisis

Author’s E-Mail Address:ccollyns@imf.org, asenhadji@imf.org

\footnotetext{
${ }^{1}$ The authors are grateful to Kalpana Kochhar for making critical suggestions on various preliminary drafts, Youkyong Kwon for superb research assistance, and Anita Jupp for efficient editing. We also would like to thank Jahangir Aziz, Raymond Brooks, Ralph Chami, Ajai Chopra, Vikram Haksar, Paul Hilbers, Roberto Rosales, and participants in an Asia and Pacific Department seminar for very helpful comments. Finally, we thank the Monetary Authority of Singapore, Bank of Indonesia, Bank Negara Malaysia, and Bank of Thailand for providing useful comments. We are of course solely responsible for any remaining errors.
} 
Contents

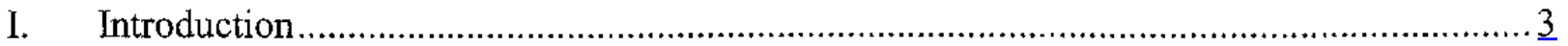

II. Determinants of Real Estate Cycles.................................................................. $\underline{5}$

III. Property Prices, Credit Cycles, and the Asian Crisis .................................................... $\underline{6}$

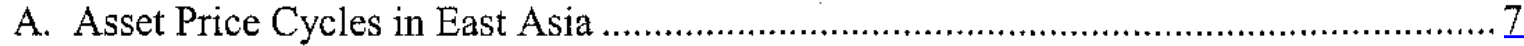

B. Asset Price Booms and Credit Cycles.............................................................. $\underline{8}$

C. Property Price Declines and Financial Distress ............................................. 11

IV. The Credit Channel to Asset Price Inflation in Asia: Some Empirical Results............... 13

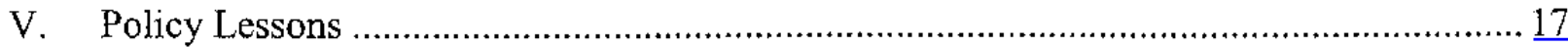

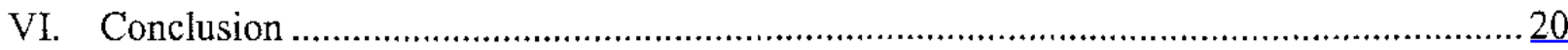

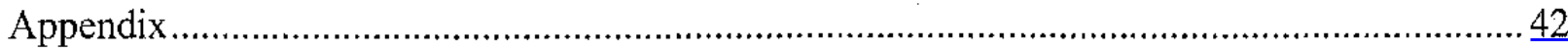

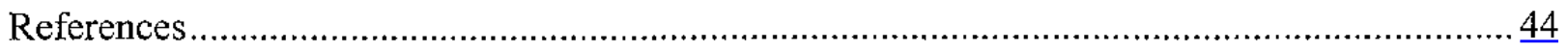

Tables

1. East Asia-Incidence of Asset Price Bubbles and Banking and Exchange Rate Crises ...... $\underline{4}$

2a. East Asian Equity Markets in the 1990s: Composite Stock Index .............................. 22

2b. East Asian Equity Markets in the 1990s: Property Stock Index ....................................23

2c. East Asian Equity Markets in the 1990s: Banking Stock Index ...................................24

3. Exposure of Asian Countries Banking System to Real Estate Sector ............................. 10

4. Determinants of Real Estate Prices ..................................................................... 15

5. Correlation Between Property and Overall Stock Market Returns.................................17

Figures

1. Selected Asian Countries: Stock Market Indices.....................................................25

2. Selected Asian Countries: Price Earnings Ratios .......................................................26

3a. Selected Asian Countries: Property Price Indices .............................................. 27

3b. Consumer Price -Housing ................................................................................. 28

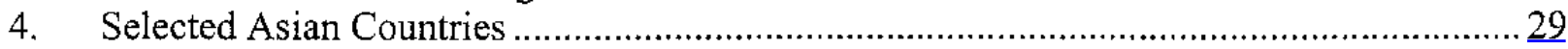

5. Real Credit and Real Property Returns ...................................................................

6. Real Credit to the Private Sector and Property Stock Reforms .................................... 31

7. Real Credit to the Private Sector and Stock Returns ................................................. 32

8. Selected Asian Countries: Stock Market Indices and NonPerforming Loans ................... $\underline{33}$

9. Selected Asian Countries: External Indicators ...................................................... 34

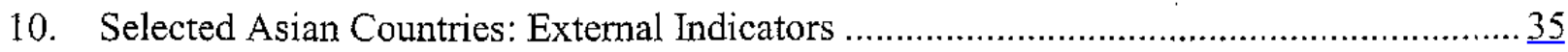

11a. Impulse Response to Cholesky One Standard Deviation: Hong Kong SAR ....................36

11b. Responses to Cholesky One Stanđard Deviaion: Korea ............................................ 37

11c. Impulse Responses to Cholesky One Standard Deviation: Thailand.............................. $\frac{38}{38}$

11d. Impulse Responses to Cholesky One Standard Deviation: Singapore............................. $\frac{39}{40}$

12. Property and Overall Stock Returns ............................................................. 40

13. Twelve-Month Correlation Between Property Stock Returns and Overall Stock Returns. 41 


\section{INTRODUCTION}

The liberalization of financial systems and the increased globalization of capital markets over the past few decades have improved the provision of financial services and the allocation of resources, but have also increased the scope for pronounced financial cycles. These cycles have often involved dramatic fluctuations in asset prices that have contributed to the amplification of the business cycle more generally, and occasionally have culminated in both banking and exchange market crises. While both industrialized and emerging market economies have been affected, emerging markets have tended to incur the heaviest costs.

Typically, these financial cycles are generated by a wave of optimism underpinned by favorable developments in the real side of the economy. This optimism contributes to the underestimation of risk, overextension of credit, excessive asset price inflation, overinvestment in physical capital, and buoyant consumer expenditures. Eventually, when expectations realign with fundamentals, the imbalances built up during the boom are corrected abruptly, as excessive optimism gives way to excessive pessimism, causing costly disruptions to both the financial system and the real economy,

Recent research on the role of the banking sector in the macroeconomy shows how the magnitude of the business cycle can be amplified through the procyclical character of bank credit. $^{2}$ The property market plays a central role in such cycles because increases in real estate prices tend to boost banks' willingness and capacity to lend, while a number of factors allow persistent deviations from efficient pricing. In a globally integrated financial world, large capital inflows can exacerbate these credit cycles. Particularly where a surge in capital flows is combined with lax regulation of the financial sector, the resulting credit cycle can end in severe financial crisis.

The Asian crisis of the late 1990s clearly followed this general pattern. Key features of the build-up to the crisis included: heady optimism in the mid-1990s in an "East Asian miracle" that was seen as capable of delivering rapid economic growth over an extended period; capital account and financial market liberalization that contributed to heavy capital inflows intermediated in considerable part through the banking system; and high rates of investment and rapid increases in asset prices, especially in the property sector as under-regulated banking systems expanded domestic credit at a tremendous pace. Subsequently, economic growth suffered set-backs, asset markets began to reverse, and both financial and corporate balance sheets started to deteriorate. Eventually, investor sentiment turned around, exacerbating this process and generating a cascading series of banking and exchange crises across the region.

\footnotetext{
${ }^{2}$ See, for example, Bernanke (1983) on the Great Depression, Bernanke and Gertler (1995), and Kiyotaki and Moore (1997).
} 
Within this familiar general story, there have been considerable differences in experience across countries. Thailand, and to a lesser extent Malaysia, experienced the most extreme property price cycles, while for Korea the property price cycle seems to have been much more subdued (Table 1). Moreover, other countries-notably Singapore and Hong Kong SARexperienced quite dramatic property price booms and slumps, and yet managed to weather the financial storm of the Asia crisis without suffering long-lasting damage. Thus, property price cycles were, in practice, neither necessary nor sufficient to a subsequent exchange and banking crisis.

Table 1. East Asia-Incidence of Asset Price Bubbles and Banking and Exchange Rate Crises

\begin{tabular}{|c|c|c|c|c|c|c|}
\hline & $\begin{array}{l}\text { Capital Inflow } \\
\text { Surge }\end{array}$ & $\begin{array}{l}\text { Real Credit } \\
\text { Growth }\end{array}$ & $\begin{array}{c}\text { Property Price } \\
\text { Bubble }\end{array}$ & $\begin{array}{l}\text { Stock Market } \\
\text { Bubble }\end{array}$ & $\begin{array}{l}\text { Banking } \\
\text { Crisis }\end{array}$ & $\begin{array}{l}\text { Exchange } \\
\text { Crisis }\end{array}$ \\
\hline Indonesia & $W$ & $\sqrt{ }$ & $\sqrt{ }$ & $\sqrt{ }$ & $\sqrt{ } v^{\prime}$ & $\sqrt{ } \sqrt{ }$ \\
\hline Korea & $\sqrt{ }$ & $\sqrt{ }$ & $\sqrt{ }$ & $\sqrt{ }$ & $\sqrt{ }$ & $\sqrt{ }$ \\
\hline Maiaysia & $\sqrt{ }$ & $\sqrt{ }$ & $\sqrt{ }$ & $\sqrt{ } \sqrt{ }$ & $\sqrt{ }$ & $\sqrt{ }$ \\
\hline Philippines & $\sqrt{ }$ & $\sqrt{ }$ & $\sqrt{ }$ & $\checkmark$ & $\sqrt{ }$ & $\sqrt{ }$ \\
\hline Thailand & $\sqrt{ } \sqrt{ }$ & $\sqrt{ }$ & $\sqrt{ }$ & $W$ & $\sqrt{ }$ & $\sqrt{ }$ \\
\hline Hong Kong SAR & $\sqrt{ } \sqrt{ }$ & $\mathrm{X}$ & $\sqrt{ }$ & $\sqrt{ }$ & $X$ & $\sqrt{ }$ \\
\hline Singapore & $\sqrt{ }$ & $\checkmark$ & $\sqrt{ }$ & $\sqrt{ }$ & $\mathrm{X}$ & $\mathrm{x}$ \\
\hline Taiwan POC & $\mathrm{X}$ & $\sqrt{ }$ & $\sqrt{ } v^{\prime}$ & $\sqrt{ }$ & $\sqrt{ }$ & $x$ \\
\hline
\end{tabular}

Note to table: The single " $~ "$ " indicates a moderate capital inflow or a bubble/crisis, a double " $V$ "indicates important capital flows or a severe bubble/crisis, and a " $\mathrm{X}$ " indicates minimal bubble/crisis. The specific calibration is explained in Appendix 1.

This paper examines the linkage between lending booms, property price cycles, and financial crisis across the range of East Asian countries. Two closely related papers have looked at these issues. Herring and Wachter (1999) develop an explanation of real estate cycles and banking crises by focusing on the interaction of credit cycles and banking behavior. The more recent paper by Hilbers, Lei, and Zacho (2001) examines the relationship between developments in real estate markets and the financial sector to determine under what circumstances, and to what extent, booms and busts in the real estate sector affect the health and stability of the financial system.

This paper builds on this previous work to examine the extent to which fast growing bank lending contributed to this property price inflation in Asia, and ultimately to the crisis after a severe correction in asset prices. The paper differs from the two papers described above by its focus on the Asian experience and the empirical evidence presented. The paper is divided into 
six sections. Section II reviews the theoretical literature on the determinants of real estate cycles. Section III discusses the Asian crisis episode, examining the extent to which there were asset price bubbles, considering the role of the banking sector in the formation of these bubbles, and analyzing the linkage between the bubbles and the financial crisis. Section IV examines empirically the determinants of real estate prices and tests the importance of the credit channel in asset price inflation in Asian economies. Section V draws some policy lessons. Section VI concludes.

\section{Determinants of Real Estate CyCles}

Under the standard asset pricing model, the price of real estate depends on the discounted present value of its expected rents. Supply in the real estate market is relatively inelastic, given the long construction lags and the fixed supply of land. Consequently, rents are typically seen as largely demand driven, depending on variables such as real GDP (which captures both the aggregate level of income per capita and population size), and anticipated real interest rates, which captures the cost of borrowing. Other relevant variables-although often not included in empirical specifications because of lack of data-include real estate taxes and mortgage interest rate deductibility, the regulatory framework for the real estate market such as zoning and building code restrictions, tenancy and lease laws, etc.

Inherent features of the real estate market - in particular imperfect information, supply rigidities, and imperfect financial markets — contribute to making the market particularly vulnerable to prolonged periods in which actual prices may deviate from their fundamental value, i.e. to the formation of price bubbles. Under such an approach, real estate price cycles can be understood as originating from a combination of imperfect information, supply rigidities, and the close relationship with imperfect financial markets ${ }^{3}$. Since the price of a real estate asset depends on the future value of fundamentals, investors may either underestimate or overestimate the fundamental price in an environment with imperfect information. In particular, investors becoming overoptimistic about expected growth could drive the price above its replacement cost. In efficient financial markets, these deviations from the fundamental price would be countered by sophisticated investors selling real estate short until the price reverted back to its fundamental value. However, there is no futures or options markets for land. The optimistic investors will remain in the market as long as prices are rising and financing is available. Long construction lags prevent a quick supply response and therefore prices may keep rising for a protracted period, and a price bubble may develop. Finally, as prices move further and further away from their fundamental value, more and more investors would eventually move to the sell side, dampening price inflation. As this process gathers momentum, prices may drop abruptly.

${ }^{3}$ See Herring and Wachter (1999) and the references therein. 
A number of authors have emphasized moral hazard and adverse selection in the banking system as factors that exacerbate such price fluctuations in the real estate sector. Moral hazard arises from explicit or implicit deposit guarantees and weaknesses in financial regulation, which provides banks with incentives to take on riskier loans without appropriately increasing their costs of funds. ${ }^{4}$ This moral hazard problem tends to induce excessive risk-taking by banks, overinvestment and excessive asset prices. The moral hazard problem is particularly acute for large banks because of the perception that such banks are "too big to fail". Adverse selection is an asymmetric information problem arising when the riskiest investors are the ones who are most actively seeking loans. Thus, investors who are the most likely to produce an adverse outcome are most likely to be selected. In periods of real estate price booms, adverse selection can exacerbate price bubbles.

More specifically, the amplification of the real estate cycle works through the following channel. ${ }^{5}$ Increases in the price of real estate may increase both the value of bank capital, to the extent that banks own real estate, and increase the value of real estate collateral, leading to a downward revision of the perceived risk of real estate lending. Consequently, an increase in real estate prices may increase the supply of credit to the real estate industry, which in turn, is likely to lead to further increases in the price of real estate. These feedback effects go into reverse when real estate prices start to decline. A decline in the price of real estate will decrease bank capital directly by reducing the value of banks' own real estate assets, and indirectly by reducing the value of loans collateralized by real estate. ${ }^{6}$ Furthermore, a decline in real estate prices is likely to reduce the costs of default and increase the perceived risk of real estate lending. As a result, real estate lending will decline, putting even more downward pressure on real estate prices, which in tum feeds back to bank lending, etc. As the banking sector weakens, banking supervision and regulation may reinforce this process by increasing capital requirements and instituting stricter rules for classifying and provisioning against real estate loans, squeezing further lending to real estate investors.

\section{Property Prices, Credit Cycles, and the Asian Crisis}

This section first presents evidence of the extent of asset price cycles in East Asia in the 1990 s, focusing on developments in the property market. Next, it considers the role of the financial system in the build-up of asset prices during the first six years of the decade,

\footnotetext{
${ }^{4}$ See Bernanke and Gertler (1995), Mishkin (1996), Krugman (1998), and Allen and Gale (2000)

${ }^{5}$ For a detailed discussion, see Herring and Wachter (1999), and BIS Annual Report, June 2001, Chapter VII.

${ }^{6}$ The precise effect of a decline in property prices on a bank's capital will depend on countryspecific accounting standards.
} 
stressing how under-regulated banking systems combined with heavy capital inflows to foster rapid growth of credit to the property sector. Third, it examines how property price declines contributed to the banking and exchange crises in the final years of the decade. The discussion covers the five crisis countries (Indonesia, Korea, Malaysia, Philippines, and Thailand), and also Hong Kong SAR, Singapore and Taiwan POC which also went through major price cycles during this period, but were able to weather the subsequent storm with less severe dislocation.

\section{A. Asset price cycles in East Asia}

While the focus of this paper is on the property market, it is useful to begin by sketching developments in equity markets, which provides a clearer picture of investor expectations and where data are more readily available. Figure 1 and Table 2 show the evolution of East Asian stock markets since 1991. Regional markets trended upwards through the first part of the decade, generally peaking around 1997 at an average 165 percent higher than their value at the start of the decade. Thailand's stock market, stands out from this general pattern, peaking much earlier than the others-on January 4, 1994-after a particularly dramatic run up in prices over 156 percent. This pre-crisis build up in stock prices was reflected in rising $P / E$ ratios to levels well above historical norms (although to nothing like the level observed in the "hi-tech" bubble of the NASDAQ in the late 1990s) (Figure 2).

Regional stock prices generally fell sharply after the onset of crisis in mid-1997 through the end of 1998, the crisis period. Korea, Malaysia, and Thailand all suffered declines of over 70 percent, while the other five countries all suffered declines of over 50 percent from peak. Subsequently, equity markets staged a recovery in 1999 as the economies turned around, but then subsided again as the global economy (and especially the electronics cycle) turned down. Equity prices in most East Asian countries in mid-2001 were not far from their level ten years earlier.

Evidence on property prices is much less readily available. For a number of countries, property price indices are collected, but coverage is not uniform and length of series often limited. Moreover, as seen in Figure 3a, the series can be highly volatile. Given these deficiencies, it is useful to supplement this data with: (i) the consumer price index (CPI) for housing which reflects rents (Figure $3 b$ ), and (ii) information from stock market indices for the property sub-sector (second panel of Figure 1). Such data must be interpreted with care and can only be a rough proxy for real estate prices. ${ }^{7}$

Drawing on these sources of information, the experience with property price movements in East Asian countries in the 1990 s seems more diverse than for equity markets.

\footnotetext{
${ }^{7}$ Note that the data are not defined uniformly across countries: for example, the property price index covers official land price for Korea, residential property price for Indonesia, housing prices for Thailand and Malaysia, etc. See data Appendix for details.
} 
- Property price data are most complete and probably most reliable for Hong Kong SAR and Singapore. These data show a definite build-up in both commercial and residential markets, through 1996 for Singapore and 1997 for Hong Kong SAR, before dropping quite sharply through 1999. This pattern, which is also evident in the CPI for housing, is consistent with real estate price bubbles for both countries, a hypothesis supported by empirical work in Kalra, et al (1999).

- There is also strong evidence of large commercial real estate cycles in Malaysia and Thailand. Stock price data suggest that, like equities, the property market peaked in Thailand in late 1993, although property price series are volatile and suggest a further price surge in 1997. In Malaysia, property prices rose steadily through 1997, before subsiding. The CPI for housing also shows significant rent inflation in Malysia prior to the crisis. ${ }^{8}$

- For Korea, Indonesia, and Philippines, property price data are either unavailable or do not show strong cyclical behavior. Nevertheless, share price data for the property sector suggest pronounced boom-bust swings in these countries, most notably in Indonesia. In Korea, the most pronounced property price bubble was associated with the construction boom leading up to the Seoul Olympic Games in 1988; but a further price run-up occurred in the early 1990s. Furthermore, the CPI for housing shows an important increase in rents up to the crisis. Only in the Philippines do stock prices in the property sector not fluctuate considerably more than stock prices of all shares (see third panel of Figure 1).

\section{B. Asset price booms and credit cycles}

The discussion of the theoretical determinants of asset price cycles in Section II provides a useful structure for examining the sources of East Asian asset price booms and boosts. In short, the combination of optimistic growth expectations, heavy capital inflows, inadequate corporate governance, and dependence on intermediation by under-regulated banks and finance companies led almost inevitably to rapid credit growth, particularly to the property sector.

First, a period of rapid economic growth without the apparent emergence of fundamental macroeconomic imbalances generated optimistic expectations that such annual growth rates could be sustained for an extended period. Four of the five crisis countries (Indonesia, Korea, Malaysia and Thailand) achieved annual growth rates greater than 7 percent during 1991-96. Current account deficits increased to high levels, but were easily financed by surging private capital inflows. Significant real exchange rate appreciation was avoided through a tight fiscal

${ }^{8}$ However, the CPI index in Thailand did not exhibit significant inflation during the early $1990 \mathrm{~s}$, highlighting the limitations of the CPI in capturing property price inflation. 
policy and monetary policies that aimed at sterilizing excess liquidity. Only the Philippines experienced a moderate fiscal deficit (around 11/2 percent of GDP on average over 1991-96).

Second, underlying the period of buoyant economic growth was a structure of public policies and corporate governance that encouraged rapid accumulation of capital. In most of the East Asian economies, public policies emphasized state support-including subsidies and directed credit-to favored firms or industries, particularly in export sectors. A combination of de facto fixed exchange rate pegs against the US dollar, capital account liberalization, and financial market deregulation-in an environment of successful economic growth-allowed firms easy access to low cost external funding. However, mechanisms were generally not in place to provide investor discipline to ensure adequate rates of return. Cross-holding share structures allowed corporate control to be exerted by wealthy families owning a small percentage of shares. Although, theoretically, borrowing from abroad can be optimal for an undercapitalized economy, the end result was low profitability of investment projects over much of East Asia. For instance, the 20 to 30 largest conglomerates in Korea achieved a rate of return on invested capital well below the cost of capital.

Third, the dominant role of the banking system in the financial system of most of the East Asian countries helped to exacerbate the scope for moral hazard. In these countries, equity and bond markets were relatively underdeveloped and the capital inflows were largely intermediated by domestic banks channeling funds to local firms (Figure 4). In some casese.g., the Bangkok International Banking Facilities (BIBF) in Thailand-the setting up of offshore banking markets served to facilitate such flows. Typically, techniques for credit assessment by banks were weakly developed, and banks tended to rely heavily on property collateral (and, to some extent equity collateral) in making loan decisions.

Fourth, regulatory structures lagged behind the rapid growth of bank intermediation. Most countries adopted Basle Committee recommendations on capital adequacy requirements, but without stringent credit assessment such requirements may provide little discipline, and in cases where performance fell short, corrective measures were typically inadequate. ${ }^{9}$ Moreover, while most countries avoided explicit deposit guarantee schemes, in practice depositors were not required to take losses when banks ran into difficulties, implying at least implicit deposit insurance and eroding barriers to moral hazard. ${ }^{10}$ In some cases (e.g. Thailand), the rapid growth of non-bank financial intermediaries, partly funded by the banks

\footnotetext{
${ }^{9}$ Out of a total of 240 Indonesian banks in April 1996, 15 did not meet the required 8 percent capital adequacy ratio, 41 did not comply with the legal lending limit, and 12 of the 77 licensed foreign exchange banks did not meet the rules on the overnight positions. See Corsetti, Pesanti, and Roubini (1998)

${ }^{10}$ See Herring and Wachter (1999).
} 
themselves, allowed regulations on bank lending to be circumvented. ${ }^{11}$

As shown in Table 3, by 1997, property exposure had risen to particularly high levels-over 30 percent of total bank loans--in Hong Kong SAR, Malaysia, Singapore, and Thailand. ${ }^{12}$ Elsewhere, the concentration was less striking, notably Korea-where capital inflows tended to be channeled more directly to the large industrial conglomerates (chaebols)-and the Philippines (where the 1990s growth experience was less dramatic.

Table 3. Exposure of Asian Countries Banking System to Real Estate Sector

\begin{tabular}{|l|c|c|r|r|c|}
\hline & $\begin{array}{c}\text { Property } \\
\text { exposure }\end{array}$ & $\begin{array}{c}\text { Collateral } \\
\text { Valuation }\end{array}$ & $\begin{array}{r}\text { Non-Performing } \\
\text { Loans }\end{array}$ & Capital-Asset Ratio \\
\hline & \multicolumn{5}{|c|}{ in percent of assets at the end of 1997} \\
\hline & \multicolumn{2}{|c|}{1997} & 1997 & 1998 & 1997 \\
\hline Korea & $15-25$ & $80-100$ & 16.0 & 22.5 & $6-10$ \\
\hline Indonesia & $25-30$ & $80-100$ & 11.0 & 20.0 & $8-10$ \\
\hline Malaysia & $30-40$ & $80-100$ & 7.5 & 15.0 & $8-14$ \\
\hline Philippines & $15-20$ & $70-80$ & 5.5 & 7.0 & $15-18$ \\
\hline Thailand & $30-40$ & $80-100$ & 15.0 & 25.0 & $6-10$ \\
\hline $\begin{array}{l}\text { Hong Kong } \\
\text { SAR }\end{array}$ & $40-55$ & $50-70$ & 1.5 & 3.0 & $15-20$ \\
\hline Singapore & $30-40$ & $70-80$ & 2.0 & 3.5 & $18-22$ \\
\hline
\end{tabular}

Source: Corsetti, Pesanti, and Roubini (1998)

Rapid growth of bank lending went hand-in-hand with escalating real estate prices. Figure 5 compares the growth rate of credit to the private sector ${ }^{13}$, deflated by the CPI, with real returns in the property sector-proxied by the growth rate of a property price index deflated by the CPI-for eight East Asian countries. ${ }^{14}$ For all countries, the positive correlation between

11 Failing banks were usually intervened by the government and forced to restructure or were merged with other banks, but typically not closed. See Dekle and Kletzer (2001).

${ }^{12}$ An important contributing factor to the large increase in property exposure in Singapore was the government's decision to relax its rules on allowing foreigners to purchase subsidized government housing from the resale market.

${ }^{13}$ Note that credit is generally underestimated because the reported credit to the private sector pertains to the banking sector only, leaving out non-bank financial intermediaries (as data for these institutions are generally not available), such as finance companies in Thailand, which played an important role in the lending boom after the financial deregulation.

${ }^{14}$ The data are quarterly. To dampen short-term fluctuations, the data have been smoothed out using a moving average of order 4 , and to eliminate seasonal factors, the growth rates are with respect to the same quarter of the previous year. 
the two series is clear. This positive correlation also holds when the property price index is replaced by the stock market index for firms in the real estate sector (Figure 6), or a composite stock market index (Figure 7), though the correlation in the latter two cases is weaker.

\section{Property price declines and financial distress}

The unwinding of the 1990s East Asian boom, and the eventual crises suffered by many East Asian countries, was obviously a complicated, multifaceted process. In part, the dramatic turnaround reflected a deterioration of performance in the real sector of these economies. Starting in 1996, export volume growth began to weaken, particularly in Indonesia, Korea, Malaysia and, especially, Thailand, as these countries faced increased competition from elsewhere (e.g., China, Vietnam, and Mexico). There were also terms of trade losses related to declining world semi-conductor prices and a hike in oil prices.

With some slowing of growth, and incipient investor concerns about the sustainability of the growth record, asset prices began to come under pressure in both equity and property markets. With banks' heavy exposure to the property market, non-performing loans began to increase, especially in Thailand where the property market downturn had started earlier in response to both increased supply following a construction boom and a tightening of monetary policy starting in 1994. Markets began to be concerned with the health of bank balance sheets, as demonstrated by falling market value of the banking sector in Korea, Malaysia, and Thailand (Figure 8).

By early 1997, reserves began to come under pressure in the context of increasingly negative investor sentiment and concern about overvaluation of regional currencies. These pressures culminated in a successful speculative attack on the Thai Baht on June 2, 1997. Speculative attacks then spread to other economies in the region perceived as suffering from similar fragilities (Figures 10). Some countries adopted an interest rate defense against the speculative attack on the exchange rate, but there were only partially successful as policy credibility was affected by perceptions that high interest rates could not be long sustained given highly leveraged balance sheets (Figure 10). ${ }^{15}$

${ }^{15}$ The stress index in Figure 10 is defined as: $\Delta e_{\$ / L}+\frac{\sigma_{e}}{\sigma_{R}} \Delta R$, where $\Delta e_{\$ / L}$ is the percent change in the bilateral exchange rate versus the USD (expressed in USD per local currency), $\Delta R$ is the percent change in reserves, and $\sigma_{e}$ and $\sigma_{R}$ are the standard deviation for $\Delta e_{\$ / L}$ and $\Delta R$, respectively. The change in reserves is multiplied by the relative standard deviation of the two variables so that the two components have the same volatility, avoiding that one component dominates the other simply because it is more volatile. See Kaminsky and Reinhart (1999) for a discussion of this index. 
Corporate and financial balance sheets-already weak--were then further undermined by the impact of sharp declines in exchange rates on the local currency value of debt, a sharp regional recession, as well as losses on their exposure to the property sector. Banks also suffered from heavy losses on loans to an over-leveraged corporate sector, against which real estate collateral provided security of declining value. The results were widespread corporate bankruptcies, collapse of confidence in domestic banking systems, and further declines in asset prices.

Beyond this broad regional story, there were significant cross-country differences in how the crisis period played out. These differences reflected, to a considerable degree the extent of asset price overvaluation and the underlying strength of domestic banking systems across countries.

- Thailand was heavily hit because it suffered from a combination of the bursting of a large property price bubble and a weak financial system. Losses were particularly heavy in the largely unregulated finance company sector, which had sharply accelerated lending to the real estate and property sectors, mainly financed from domestic banks from funds channeled through the BIBF. While the peak in property prices occurred in December 1993, strong investment in real estate sector continued until the crisis, reflecting perhaps time-to-build lags or a perception by investors that declining prices in the real estate sector would be short-lived.

- Malaysia also experienced a sharp decline in real estate prices and a heavy build-up in non-performing loans. However, underlying fundamentals remained stronger, particularly since Malaysian financial institutions were better regulated and capitalized. In consequence, the stress on the exchange rate, while marked, was not as dramatic as occurred in Thailand. Moreover, a blanket guarantee of deposits announced at the end of 1997 was credible, helping to avoid a general bank run (Meesook et at 2001).

- Indonesia and Korea both underwent severe foreign exchange and banking crises, but in these cases the banking crisis in both countries was largely generated by defaults on dollar-denominated loans extended to highly leveraged connected firms. The property sector played a smaller role, reflecting less obvious property price bubbles and smaller bank exposure to the property sector. In the case of Korea, the bursting of the bubble in both equities and property prices occurred before the crisis.

- Philippines had experienced a more moderate economic upswing in the first half of the 1990 s and correspondingly suffered a less severe downturn during the Asia crisis period. Like Indonesia and Korea, property sector developments played less of a role.

Hong Kong SAR and Singapore were economies with very pronounced property market upswings in the first half of the 1990 s, with very heavy bank exposure to the sector. These cases are discussed in more detail in Hilbers, Lei, and Zacho (2001). In Singapore, the 
authorities had become concerned about the extent of the surge in property prices in 1996 and had taken steps to take some steam out of the market ${ }^{16}$. Similarly, in Hong Kong SAR the authorities responded to the build-up in real estate prices by mid-1997 by announcing a sharply stepped up pace of making public land available for private development. Both economies experienced pressure in the exchange market during the crisis period, but were able to respond effectively to contain the pressures-in Singapore by allowing some increased exchange rate flexibility and in Hong Kong SAR through an aggressive interest rate defense of the currency board regime combined with equity market intervention to counter speculative attacks by hedge funds. Property prices dropped sharply in both economies, contributing to some increase in non-performing loans. Nevertheless, the rise in problem loans was relatively modest compared to other East Asian countries, while the robust capitalization of the major banks in these countries, together with the avoidance of deep recession and healthier balance sheets allowed these banking systems to weather the storm without experiencing bank runs or other forms of major distress.

\section{The Credit Channel to Asset Price inflation in Asia: Some Empirical. RESULTS}

The thrust of the discussion so far is that bank lending in the Asian economies has contributed to excessive asset price inflation, in particular in the real estate market, and the bursting of the bubble in these markets contributed significantly to the financial crisis in Asia. In the previous section, it was shown that there was a correlation between bank lending and asset prices (Figures 6-8). This section attempts a more rigorous quantitative assessment of the relationship between credit growth and real estate prices based on OLS regressions of real estate prices on a set of relevant factors, drawing on data from a panel of four East Asian countries for which quarterly property price data exist (Hong Kong SAR, Korea, Singapore and Thailand). ${ }^{17}$ Individual country VARs are also estimated, to allow for more flexible dynamics and feedback effects.

The specification has been kept parsimonious and follows the empirical literature which finds that GDP per capita is the main determinant of property prices (see discussion in Section II). It captures both the procyclical behaviour of property prices and the economy's income which is one of the main determining factor for the demand for business and residential property. The

\footnotetext{
${ }^{16}$ In mid-1996, in response to the property market boom in 1994-95-when property prices rose by an average of 30 percent-the authorities introduced a number of anti-speculative measures. The measures included capital gains taxes and stamp duties; limiting bank loans to 80 percent of the purchase price; and increases in the supply of government land for residential development.

${ }^{17}$ Malaysia, and Taiwan POC have only semi-annual data, Indonesia has only data for residential property, and the Philippines has no property price data.
} 
dependent variable is a composite property price index reflecting both residential and nonresidential property prices, deflated by the CPI ( $p p i)$. Independent variables include credit to the private sector deflated by the CPI $\left(c_{p}\right)$, real gdp per capita ( $g d p p c$ ), and a dummy variable in some equations. The dummy variable $d_{l}$ takes one for the period 1979:1 to 1996:4, and zero thereafter. The dummy variable $d_{2}$ takes one when the quarterly growth rate of ppi is positive and zero otherwise. The dlog operator indicates first difference in logs. The notation with FE and w/o FE indicates whether the equation has been estimated with or without fixed effects, respectively. ${ }^{18}$

Interest rates (both domestic and foreign) were included in the regression but were found to be statistically insignificant, and therefore were dropped from the final specification. ${ }^{19}$ In other words, interest rates do not significantly increase the explanatory power of the model once the credit variable is included in the regression.

The panel regression results are presented in Table 4. Equation (1) is estimated without fixed effects. Both coefficients are statistically significant at 1 percent and the magnitude of the coefficient estimate on real credit seems to suggest a powerful effect of credit on property price inflation: an increase in real credit by 10 percent implies an increase in property prices by 8 percent. Considering that real credit has been growing annually in the range 9-36 percent during the period $1990-97$ in the 5 crisis countries ${ }^{20}$, the cumulative effect of this credit boom on property prices has been substantial. As expected, property prices are strongly related to real GDP growth, suggesting a substantial pro-cyclical element.

This simple specification explains 32 percent of the variance of property price growth rates. An important question is whether this equation is misspecified because of omitted variables, and in particular, variables that are important in expaining cross-country heterogeneity. To test the robustness to potential omitted variables, the same equation was estimated using fixed effects (equation 2). Including fixed effects does not significantly alter the results. One interesting question is whether the response of property prices was different before and after the crisis. A simple way to answer this question is to add a dummy variable to the slope on real credit. This is done in equation (3) where an additional variable is defined as the product of a dummy variable $d_{l}$ and the growth rate of real credit. The dummy variable $d_{l}$ takes one for the period prior to 1997 and zero otherwise. The response of property prices to real credit during the period 1979:1-1996:4 was two and half times larger than the response

${ }^{18}$ Fixed effects control for some of the cross-country heterogeneity.

${ }^{19}$ The decision to eliminate statistically insignificant variables was guided by the fact that the same specification will be used to estimate individual country VARs for which parsimony is important given the small range of individual country time series.

${ }^{20}$ Indonesia, Korea, Malaysia, Philippines, and Thailand. 
during the period 1997:1 to 2001:1 (the coefficient on real credit declined from 0.961 during the first period to 0.393 during the second period).

Table 4. Determinants of Real Estate Prices

\begin{tabular}{|c|c|c|c|c|}
\hline \multirow{2}{*}{ Independent variables } & \multicolumn{3}{|c|}{ Dependent Variable: dlog(ppi/ppi(-4)) } & \multirow[b]{2}{*}{$\begin{array}{c}\text { (4) } \\
\text { w/O FE }\end{array}$} \\
\hline & $\begin{array}{c}(1) \\
\text { w/o FE }\end{array}$ & $\begin{array}{c}\text { (2) } \\
\text { with } \mathrm{FE}\end{array}$ & $\begin{array}{l}(3) \\
w / o F E\end{array}$ & \\
\hline$d_{2}$ & & & & $\begin{array}{l}0.10 \\
(3.70)^{*}\end{array}$ \\
\hline $\mathrm{d} \log \left(c_{p} / c_{p}(-4)\right)$ & $\begin{array}{l}0.805 \\
(4.55)^{*}\end{array}$ & $\begin{array}{l}0.748 \\
(4.56)^{*}\end{array}$ & $\begin{array}{l}0.393 \\
(1.89)^{* * *}\end{array}$ & $\begin{array}{l}0.442 \\
(2.50)^{*}\end{array}$ \\
\hline$d_{l}{ }^{*} \operatorname{d} \log \left(c_{p} / c_{p}(-4)\right)$ & & & $\begin{array}{l}0.568 \\
(2.15)^{* *}\end{array}$ & \\
\hline$d_{2}{ }^{*} \mathrm{~d} \log \left(c_{p} / c_{p}(-4)\right)$ & & & & $\begin{array}{l}0.800 \\
(2.65)^{*}\end{array}$ \\
\hline $\operatorname{dlog}(g d p p c / g d p p c(-4))$ & $\begin{array}{l}1.789 \\
(7.66)^{*}\end{array}$ & $\begin{array}{l}1.782 \\
(7.07)^{*}\end{array}$ & $\begin{array}{l}1.749 \\
(7.13)^{*}\end{array}$ & $\begin{array}{l}1.210 \\
(5.11)^{*}\end{array}$ \\
\hline$N$ & 213 & 213 & 213 & 213 \\
\hline$R^{2}$ & 0.32 & 0.35 & 0.33 & 0.45 \\
\hline
\end{tabular}

Note to table: t-statistics using White's heteroskedasticity-consistent standard errors are given between parentheses. Statistical significance at 1,5 , and 10 percent is indicated by ${ }^{*}, * *, * *$, respectively.

Finally, is the response of property prices identical during boom and bust periods? Equation (4) tests this nonlinearity in real credit by adding to the basic equation an interactive term defined as a product between $d_{2}$ and the growth rate of real credit. Interestingly, the response of property prices is asymmetric and depends on whether property prices are rising or falling: the response to real credit is much stronger during periods of rising property prices than during periods of decline. A 10 percent increase in real credit will boost property prices by 12.4 percent during periods of rising property prices but by only 4.4 percent during periods of decline. This may reflect the fact that banks tend to reduce the share of credit to the property sector, and therefore decrease their exposure to the real estate market once the real estate price bubble bursts. It may also reflect data problems as the decline in credit during bust periods may be exaggerated because of write-offs during crises. Finally, it can also reflect downward rigidity of property prices, at least in the short term as investors may be reluctant to sell property at a price lower than the purchase price.

To sum up, the results above suggest that: (i) property prices are strongly procyclical, (ii) bank lending has indeed significantly contributed to property price inflation in Asia during the period prior to the crisis, (iii) the response of property prices was significantly stronger before 
the crisis, and (iv) the response of property prices to credit is asymmetric in the sense that the response during periods of rising property prices is three time the response during periods of declining prices.

While the above results are suggestive, the specifications adopted in Table 4 neglect two important issues. First, they assume that causality runs only from real credit to property prices but not vice-versa. ${ }^{21}$ Second, there is no dynamics in the chosen specifications. To address these issues, these results are complemented by running individual-country VARs with the same three variables: the growth rates of $p p i, c_{p}$, and $g d p p c$. The sample of countries includes Hong Kong SAR, Korea, Singapore, and Thailand. Data are quarterly. ${ }^{22}$ The lag length, selected by the Schwarz criterion, is 2 . The impulse response functions and associated confidence intervals are depicted in Figures 12a to 12d. The 9-panel graphs for each country show the impulse response of each of the three variables to a shock originating from one of the three variables. The first graph in the second row depicting the impulse response of $p p i$ to a $c_{p}$ shock is the most relevant.

The results from this VAR exercise tend to confirm the results from the panel estimation in Table 4. For all countries, a shock to real credit increases property prices for at least the next 6 quarters. For some countries, the effect partially reverses itself after approximately 6 quarters. The discussion in the second section suggests that causality between real credit and real estate prices runs both ways, and the empirical evidence tends to corroborate this view. Indeed, the impulse response of real credit to a shock from real property returns is positive, except for Thailand for which it is slightly negative but statistically insignificant. The procyclical behaviour of property prices suggested by the panel regressions also holds for the VAR estimation results. As expected, an increase in real credit stimulates economic activity (all countries show a positive effect of real credit on real GDP). Changing the ordering of the variables does not significantly change the results.

The empirical evidence above suggests that there has been indeed a credit channel to property price inflation. Does the credit channel also affect other asset prices? A similar VAR exercise where property returns ( $p p i$ ) has been replaced by overall stock returns shows that high credit growth tends to inflate other asset prices. However, the effect is weaker than for the property market. In fact, property returns and overall stock market returns are highly correlated as shown in Figure $12 .{ }^{23}$ Figure 13 shows the evolution of the correlation between these two

${ }^{21}$ A formal Granger-Causality test for each country generally fails to reject causality in both directions.

${ }^{22}$ For data definition and sample periods, see data appendix.

23 These two series are computed as the annual percentage change of a property market index and the annual percentage change of an overall stock market index, respectively. The series are monthly and have been smoothed out using a moving average of order 12 . 
series for 10 Asian countries. ${ }^{24}$ At a glance, there is no clear pattern over time in these correlations, and in particular, there is no strong evidence of increased correlation during the Asian crisis. However, the regressions in Table 5 below detect some regularities.

The variables are property returns $\left(r_{p}\right)$, overall stock market returns $\left(r_{o s}\right)$, a dummy variable $d_{1}$ which takes the value one when $r_{p}$ is negative and zero otherwise. Henceforth, the correlation between $r_{p}$ and $r_{o s}$ will be denoted by $\rho\left(r_{p}, r_{o s}\right)$. Equation (1) shows that there is only a weak linear relationship between $\rho\left(r_{p}, r_{o s}\right)$ and $r_{p}$. However, there seems to be a nonlinear relationship between $\rho\left(r_{p}, r_{o s}\right)$ and $r_{p}$. For instance, adding a quadratic term in equation (2) increases the explanatory power of the relationship, which implies that $\rho\left(r_{p}, r_{o s}\right)$ tends to increase in periods of high volatility. Similarly, relaxing the assumption of symmetry strengthens the relationship (equation (3)). Equation (3) shows that the correlation is significantly stronger when property returns are negative.

Table 5. Correlation Between Property and Overall Stock Market Returns

\begin{tabular}{llll}
\hline \multirow{2}{*}{ Independent variables } & \multicolumn{3}{c}{ Dependent Variable: correlation between $r_{p}$ and $r_{o s}$} \\
& $(1)$ & $(2)$ & $(3)$ \\
\hline$r_{p}$ & 0.669 & 0.412 & 2.419 \\
& $(1.14)$ & $(0.75)$ & $(3.33)^{*}$ \\
$r_{p}^{2}$ & & & \\
& & 26.36 & \\
$d_{1}^{*} r_{p}$ & & $(3.87)^{*}$ & \\
& & & -3.971 \\
$N$ & & & $(-2.59)^{*}$ \\
$R^{2}$ & 120 & 120 & 120 \\
\hline
\end{tabular}

Note to table: t-statistics using White's beteroskedasticity-consistent standard errors are given between parentheses. Statistical significance at 1 per cent is indicated by *.

\section{Policy Lessons}

This paper does not provide scope for a full assessment of the policy lessons from the Asia crisis. ${ }^{25}$ Instead, this section seeks to draw on the paper's analysis of the experience with the

${ }^{24}$ The correlation in year $t$ between the two series is the correlation coefficient between the two series over the 12 months of year $t$.

${ }^{25}$ A more comprehensive analysis of the Asian Crisis can be found, for example, in WEO (December 1997), Kalpana et. al. (1998), Berg (1999), and Meesook et. al. (2001). 
asset price cycles in East Asia over the 1990s to underline a number of important policy lessons drawn elsewhere (see, for example, Herring and Wachter (1999), and Lane et. al. (1999)).

Most important, the Asian experience with property price booms and busts, and the consequences for financial stability, reinforce the critical importance of strong bank regulation, both to reduce risks of the development of a bubble in the first place and to contain the disruptive costs when bubbles burst.

Development of real estate bubbles would be discouraged by steps to restrain the growth of bank credit to the property and related sectors, in particular by:

- Strengthening credit assessment and reducing reliance on collateral as the basis for credit decisions. The Asian approach of placing heavy reliance on collateralization for credit assessment imparted a strong pro-cyclical bias to bank lending, especially to the property sector that was extremely damaging to the balance sheet once the cycle reversed. Such risks would be reduced by encouraging banks to look more broadly at the soundness of a borrower's business prospects and capacity for loan repayment in credit risk assessment, while tightening underwriting standards for real estate lending (e.g. maximum loan to value ratios), especially when property prices are rising rapidly and may be deviating significantly from fundamental values.

- Reducing moral hazard in the banking system. The Asian experience underlines that moral hazard can be particularly damaging by encouraging rapid credit growth in an environment where shareholder oversight is generally weak, and legal remedies costly and ineffective. Key measures to contain moral hazard would include (i) a transparent and credible framework for deposit insurance and bank resolution that ensures that large creditors and depositors can suffer losses (to improve market discipline), (ii) stringent capital adequacy requirements to ensure that bank owner's capital is truly at risk, and (iii) more demanding accounting standards (particularly to provide more realistic information on asset valuation to strengthen market discipline by investors and creditors.

- Applying a comprehensive approach to bank regulation. The Thai experience clearly demonstrated the systemic dangers of allowing a lightly regulated sector with wide lending power to play an important part in financial intermediation. Moreover, sophisticated risk management systems (including rigorous stress testing) would discourage banks from taking on large exposure to market risk (e.g., in the property market).

- Encouraging alternative sources of financing for the real estate sector. In the U.S., the development of the real estate investment trust (REIT) has broadened the investor base over the past twenty years and increased the availability of equity financing for this sector. Japan has more recently introduced a similar vehicle. The more sophisticated 
East Asian emerging markets could also consider this approach, although successful development of such a market would depend on considerably enhancing legal and regulatory frameworks for the property sector to provide adequate liquidity and investor protection.

Of course, even with generally well managed banks and strong regulations, the emergence of asset price bubbles cannot be ruled out. Lending decisions are inevitably influenced by a human tendency to follow what others are doing, and moral hazard can never be entirely excluded from bank intermediation. However, the Hong Kong SAR and Singapore experience during the late 1990s demonstrates that highly capitalized banks can better absorb the costs of the subsequent asset price deflation.

The Asian experience also supports the view that well balanced macroeconomic and related policies help to avoid asset price bubbles and contain the disruptive impact of subsequent collapses. The difficulty, of course, is to reach the correct judgment that a run-up in asset prices does reflect "irrational exuberance" in expectations or policy distortions rather than a genuine increase in long-term productivity of assets in the economy. Nevertheless, as seen in Thailand, Korea and Indonesia, the potentially enormous costs arising from mistakes would suggest a conservative policy erring on the side of caution.

- With the benefit of hindsight, the rapid influx of funds into East Asian emerging markets in the first half of the 1990s, especially short-term debt flows was larger than justified by productive opportunities, and fuelled speculative activities in the property sector (especially Thailand and Malaysia) as well as over-investment and overleveraged balance sheets (e.g., Korea and Indonesia). Learning from this experience, it is now widely recognized that capital account liberalization must be carefully phased in line with domestic financial regulation and occur in a sound macroeconomic environment. Recently, some observers have recommended a much more restrictive approach to debt flows, particularly in Asia where internal saving generation is already strong (e.g., Krueger (2000) and Horiguchi (2001)).

- There is also clearly benefit to a conservative approach to monetary policy that takes account of asset price developments in reaching judgments on short-term policy settings. The East Asian countries ran into difficulties in part because pegging the exchange rate to the dollar for much of the 1990 s meant that monetary conditions depended in considerable part on the terms at which foreign investors would lend to the country. This approach provided little protection against a cycle in which positive investor perceptions and rising asset prices were mutually reinforcing. An alternative approach would be based on adopting an independent monetary policy aimed at ensuring stable macroeconomic conditions in the context of a floating exchange regime. In such a context, decisions on monetary policy settings would involve inter alia an assessment of the potential for over-heating coming from excessive asset price valuation, even where over-heating could not be immediately observed in goods price data. 
- Finally, there is room to manipulate policy settings that directly affect the property sector as a means to moderate property price movements before they become extreme. Singapore followed this route in 1996, increasing public land sales and taxes on capital gains from real estate, and limiting bank loans to 80 percent of the purchase price, thus helping to deflate the build-up in land prices, reducing the country's vulnerability during the Asia crisis in 1997-98.

\section{Conclusion}

This paper examines the link between lending booms, asset price cycles, and financial crises across East Asian countries. The paper presents evidence of the extent of asset price cycles in East Asia in the 1990s, focusing on the development in the property market. It suggests that the build-up of asset prices during the first six years of the decade and the subsequent financial crisis can be largely explained by the interaction of imperfections in financial markets, inadequate regulation and lax supervision, and frictions in the real estate market. Econometric evidence supports the hypothesis of a credit channel to asset price inflation in Asia. Furthermore, the results show that: (i) the effect is considerably stronger in the real estate market than in the equity market, (ii) the response of property prices was significantly stronger before the crisis; (iii) the response of property prices to credit is asymmetric in the sense that the response during periods of rising property prices is three time the response during periods of declining prices; and (iv) asset returns in the property market are highly correlated to asset returns in the overall market. This correlation tends to increase in periods of high volatility and is significantly stronger during bust periods.

While this paper does not provide scope for a full assessment of the policy lessons from the Asia crisis, some important policy lessons related to the experience with the asset price cycles in East Asia over the 1990s can be drawn:

- The varying experience across East Asia with property price booms and busts and the consequences for financial stability-particularly the greater ability of Hong Kong SAR, Malaysia, and Singapore to weather the impact of sharp declines in asset prices-reinforce the critical importance of strong bank regulation. Steps to reduce the risk of future asset price bubbles, and to contain the disruptive impact when bubbles burst: strengthening credit assessment, reducing moral hazard, applying a comprehensive approach to bank regulation, and encouraging alternative, non-bank source of financing for the real estate sector.

- The Asian experience also supports the view that well balanced macroeconomic and related policies contribute to avoiding asset price bubbles and containing the disruptive impact of subsequent collapses. Important elements include independent monetary policy with flexible exchange rate policies, and carefully sequenced capital account liberalization. The difficulty, of course, is to reach the correct judgment that a run-up in asset prices does reflect "irrational exuberance" in expectations or policy distortions 
rather than a genuine increase in long-term productivity of assets in the economy. Nevertheless, as seen in Thailand, Korea and Indonesia, the potentially enormous costs arising from mistakes would suggest a conservative policy erring on the side of caution. 
Table 2a. East Asian Equity Markets in the 1990s: Composite Stock Index

\begin{tabular}{|c|c|c|c|c|c|c|}
\hline & Date of Peak & $\mathrm{P} / \mathrm{E}$ ratio at peak & $\begin{array}{l}\text { Increase from } \\
1 / 91 \text { to } \text { pcak }^{1}\end{array}$ & Date of trough & $\mathrm{P} / \mathrm{T}$ ratio at trough & $\begin{array}{l}\text { Decline from } \\
\text { peak to trough }{ }^{2}\end{array}$ \\
\hline Indonesia & Jun 97 & 22.2 & 89.2 & Feb 99 & 3.2 & -61.9 \\
\hline Korea & Oct 94 & 19.5 & 74.0 & Jun 98 & 9.3 & -73.1 \\
\hline Malaysia & Feb 97 & 28.0 & 155.5 & Aug 98 & 11.1 & -76.2 \\
\hline Philippines & Jan 97 & 27.9 & 352.2 & Jul 98 & 11.6 & -53.0 \\
\hline Thailand & $\operatorname{Jan} 94$ & 26.1 & 155.6 & Aug 98 & 8.0 & -87.3 \\
\hline Hong Kong SAR & Jul 97 & 18.6 & 404.6 & Aug 98 & 7.1 & -55.6 \\
\hline Singapore & Feb 96 & n.a. & 76.0 & Aug 98 & 11.8 & -55.6 \\
\hline Taiwan POC & Jul 97 & 39.3 & 150.2 & $\operatorname{Jan} 99$ & 24.5 & -66.5 \\
\hline
\end{tabular}

Source: CElC and authors' calculations.

11: The percent change in the stock price index from January 1991 to the last peak before the crisis.

/2: First trough after the crisis 
Tablc 2b. East Asian Equity Markets in the 1990s: Property Stock Index

\begin{tabular}{|c|c|c|c|c|c|c|}
\hline & & & & & & \\
\hline Indonesia & Jul 97 & 20.0 & $66.5(\operatorname{Jan} 96)$ & Mar 99 & -6.0 & -88.7 \\
\hline Korea & Oct 94 & n.a. & 49.7 & Jun 98 & n.a. & -91.2 \\
\hline Philippines & Jan 97 & 38.7 & 49.6 (Oct 94) & Sep 98 & 7.2 & -72.5 \\
\hline Thailand & Jan 94 & 54.9 & 285.3 & Aug 98 & 5.8 & -99.1 \\
\hline Hong Kong SAR & Jul 97 & 16.2 & 413.7 & Aug 98 & 4.0 & -73.0 \\
\hline
\end{tabular}

Source: CEIC and authors' calculations.

/1: The percent change in the stock price index between January 1991 (or if data covers a shorter span, from the first observation available given between parentheses) and the last peak before the crisis.

/2: First trough after the crisis 
Table 2c Fast Asian Equity Markets in the 1990s: Banking Stock Index

\begin{tabular}{|c|c|c|c|c|c|c|}
\hline & Date of Peak & $\mathrm{P} / \mathrm{E}$ ratio at peak & $\begin{array}{l}\text { Increase from } \\
1 / 91 \text { to peak }\end{array}$ & Date of trough & $\mathrm{P} / \mathrm{E}$ ratio at trough & $\begin{array}{l}\text { Decline from } \\
\text { peak to trough }{ }^{\prime 2}\end{array}$ \\
\hline Indonesia & Jun 97 & 14.0 & $93.7(\operatorname{Jan} 96)$ & Aug 01 & n.a. & -82.4 \\
\hline Korea & Oct 94 & n.a. & 4.7 & Sep 98 & n.a. & -89.8 \\
\hline Malaysia & Feb 97 & 28.8 & 432.0 & Aug 98 & -232.4 & -85.2 \\
\hline Philippines & Feb 97 & 30.4 & n.a. (Nov 96) & Aug 98 & 6.4 & -71.2 \\
\hline Thailand & $\operatorname{Jan} 96$ & 15.8 & 533.9 & Aug 98 & 10.6 & -93.9 \\
\hline Hong Kong SAR & Jul 97 & 19.4 & 986.3 & Scp 98 & 8.9 & -50.3 \\
\hline Singapore & Feb 97 & n.a. & n.a. $(\operatorname{Jan} 97)$ & Sep 98 & 8.7 & -62.2 \\
\hline Taiwan POC & $\operatorname{Jan} 96$ & 31.6 & 533.9 & Aug 98 & 18.5 & -93.9 \\
\hline
\end{tabular}

Source: CEIC and anthors' calculations.

/1: The percent change in the stock price index between January 1991 (or if data covers a shorter span, from the first observation available given between parentheses) and the last peak before the crisis.

12: First trough after the crisis 
Figure I

Selected Asian Countries: Stock Market Indices

(January 1999=100)
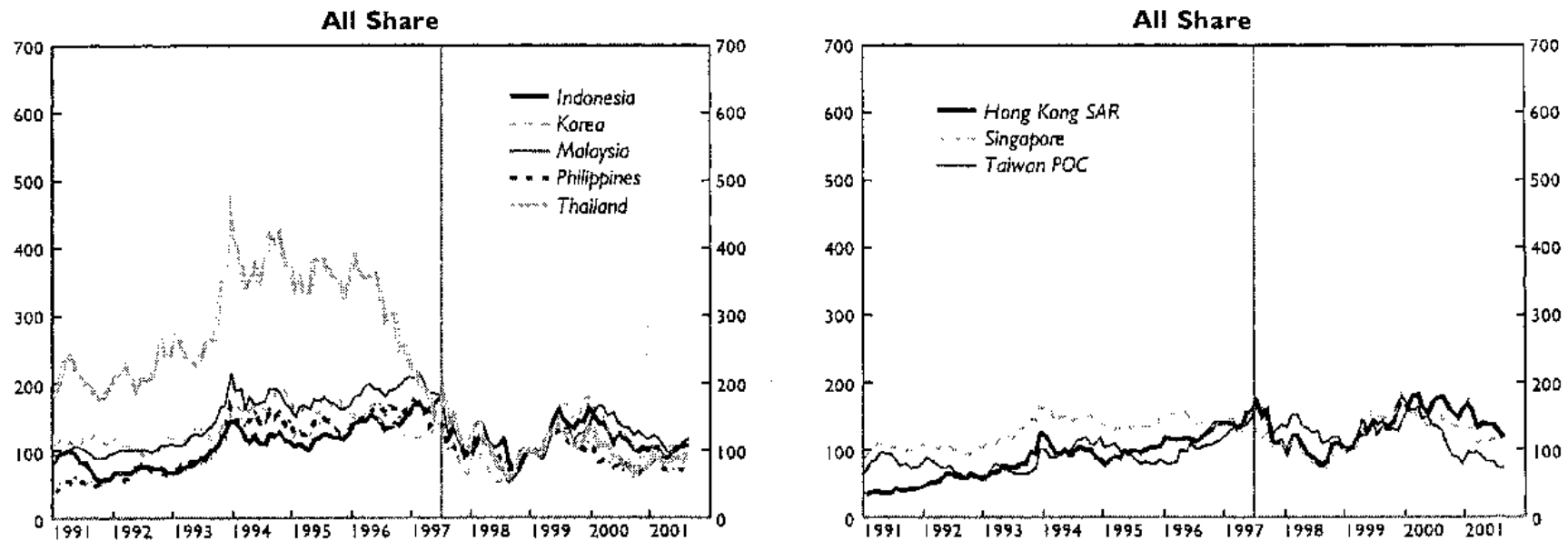

Property
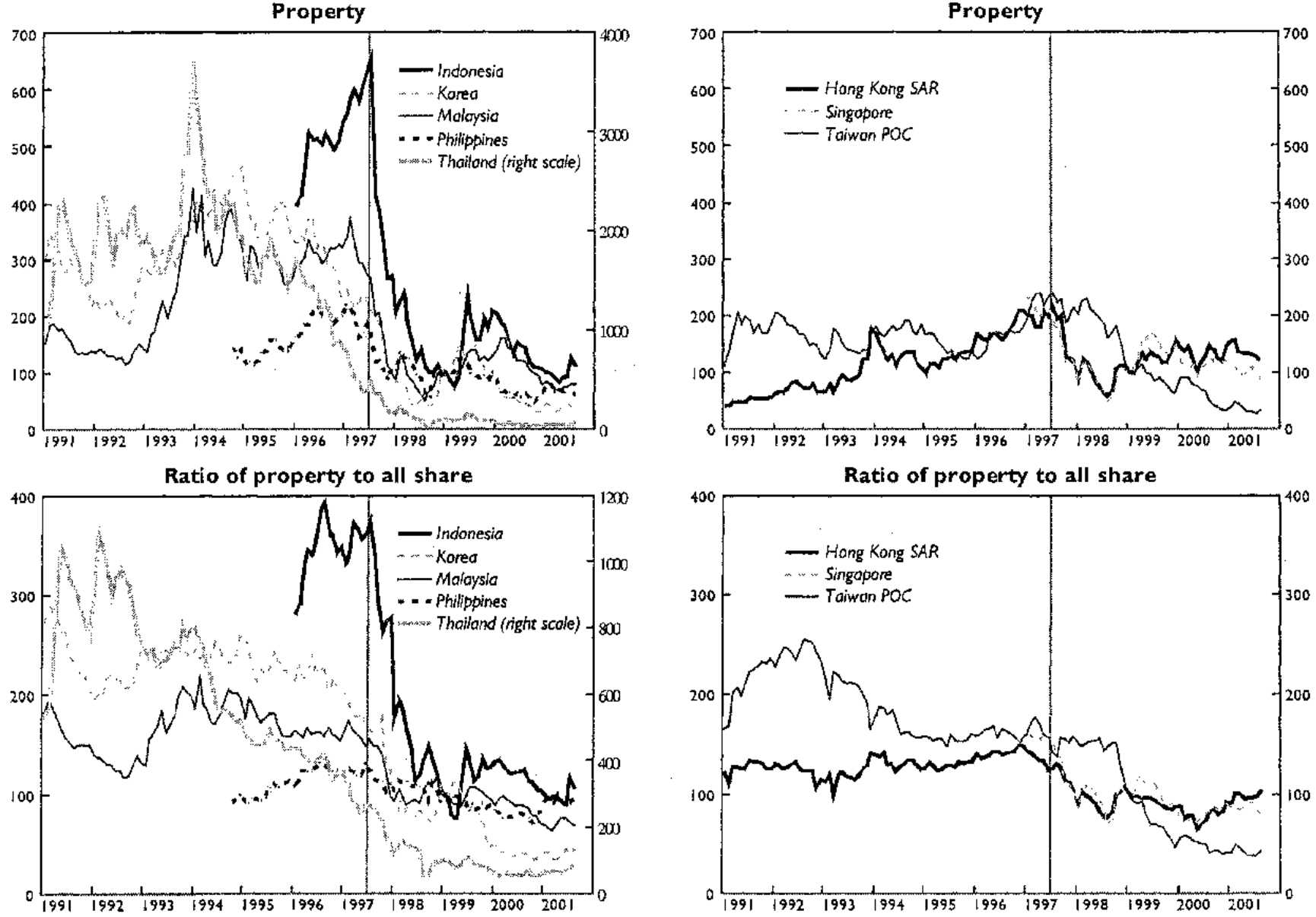

Source: CEIC 
Figure 2

Selected Asian Countries: Price Earnings Ratios
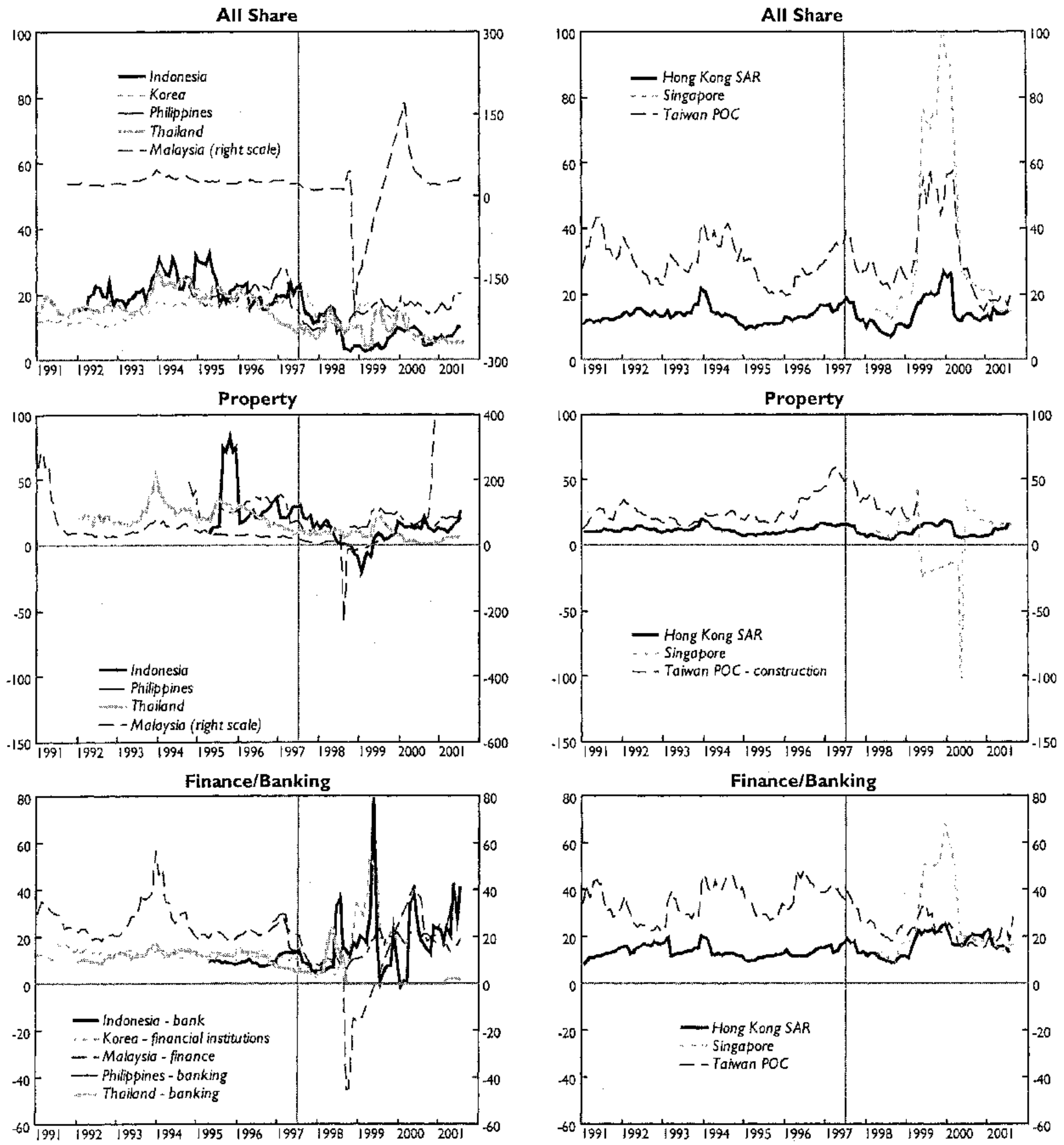

Source: CEIC 
Figure 3a

Selected Asian Countries: Property Price Indices
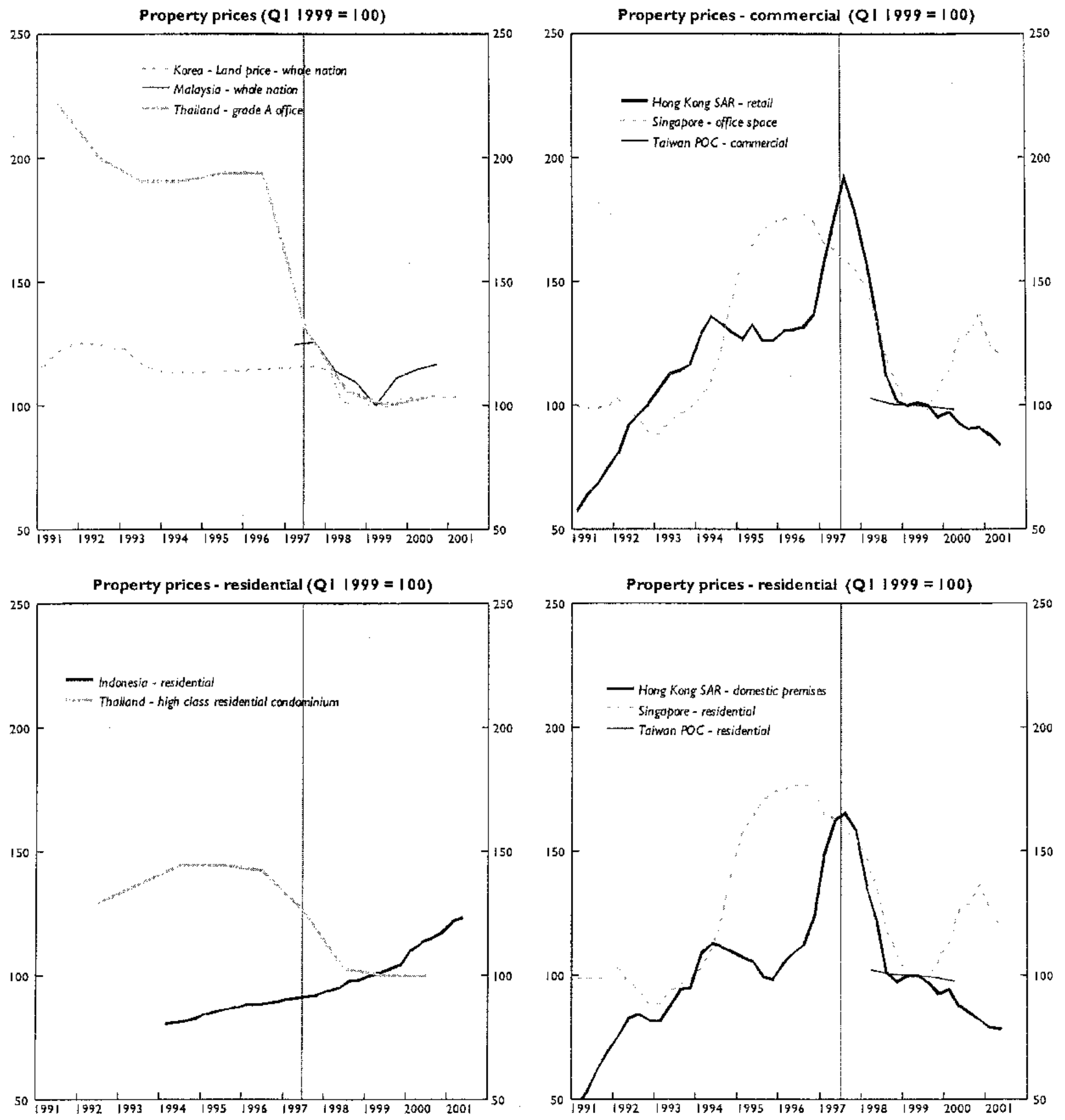

Source: CEJC and staff estimates. 
Figure 3b. Selected Asian Countries: Consumer Price - Housing

(January 1991=100)
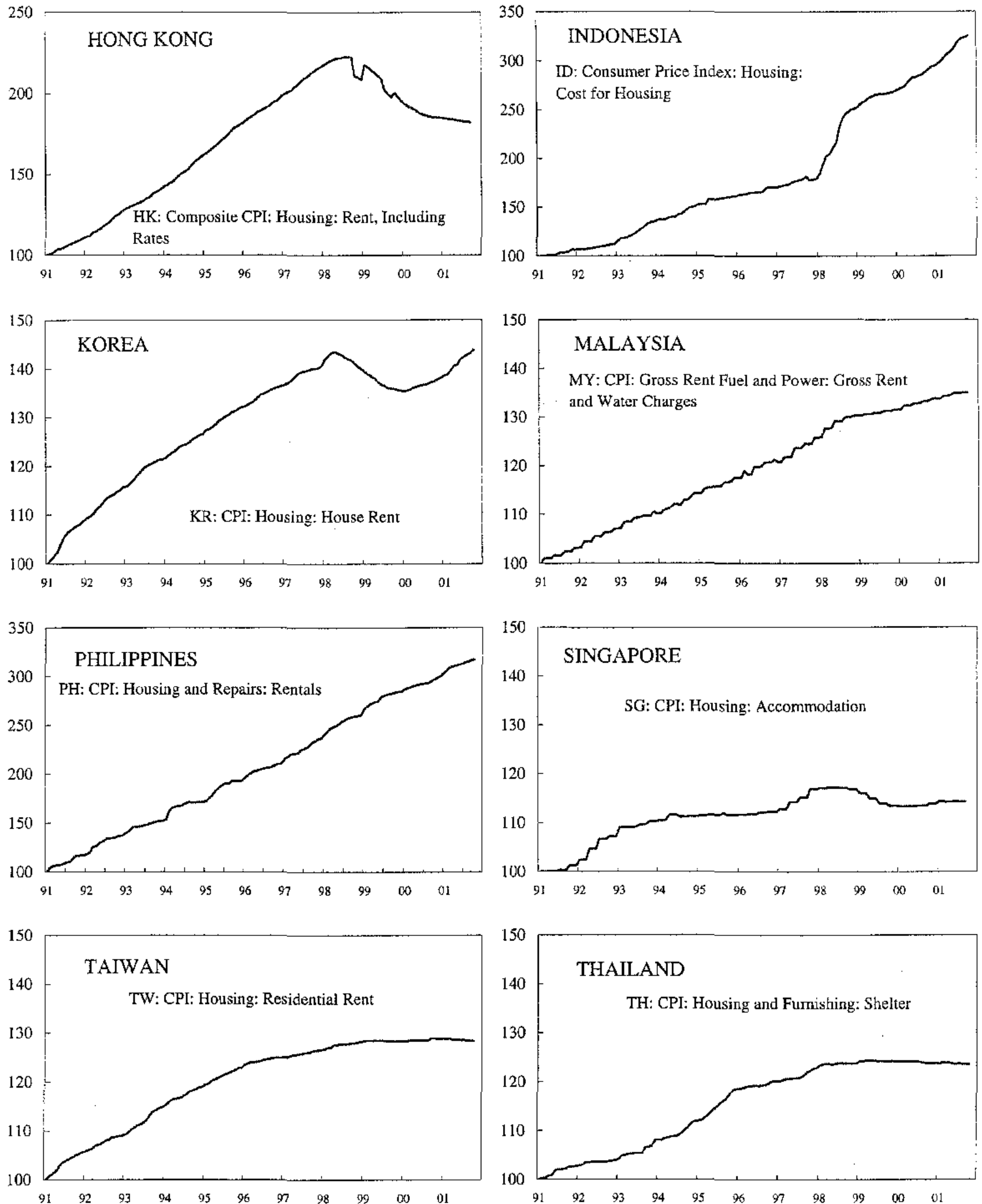

Source: CEIC.

Break in series: Honkg Kong, Oct. 1999; Indonesia, Mar. 1996; Malaysia, Dec. 1993;

Philippines, Dec. 1996; Singapore, Dec. 1998. 
Figure 4

Selected Asian Countries: Capital Flows and Credit Growth
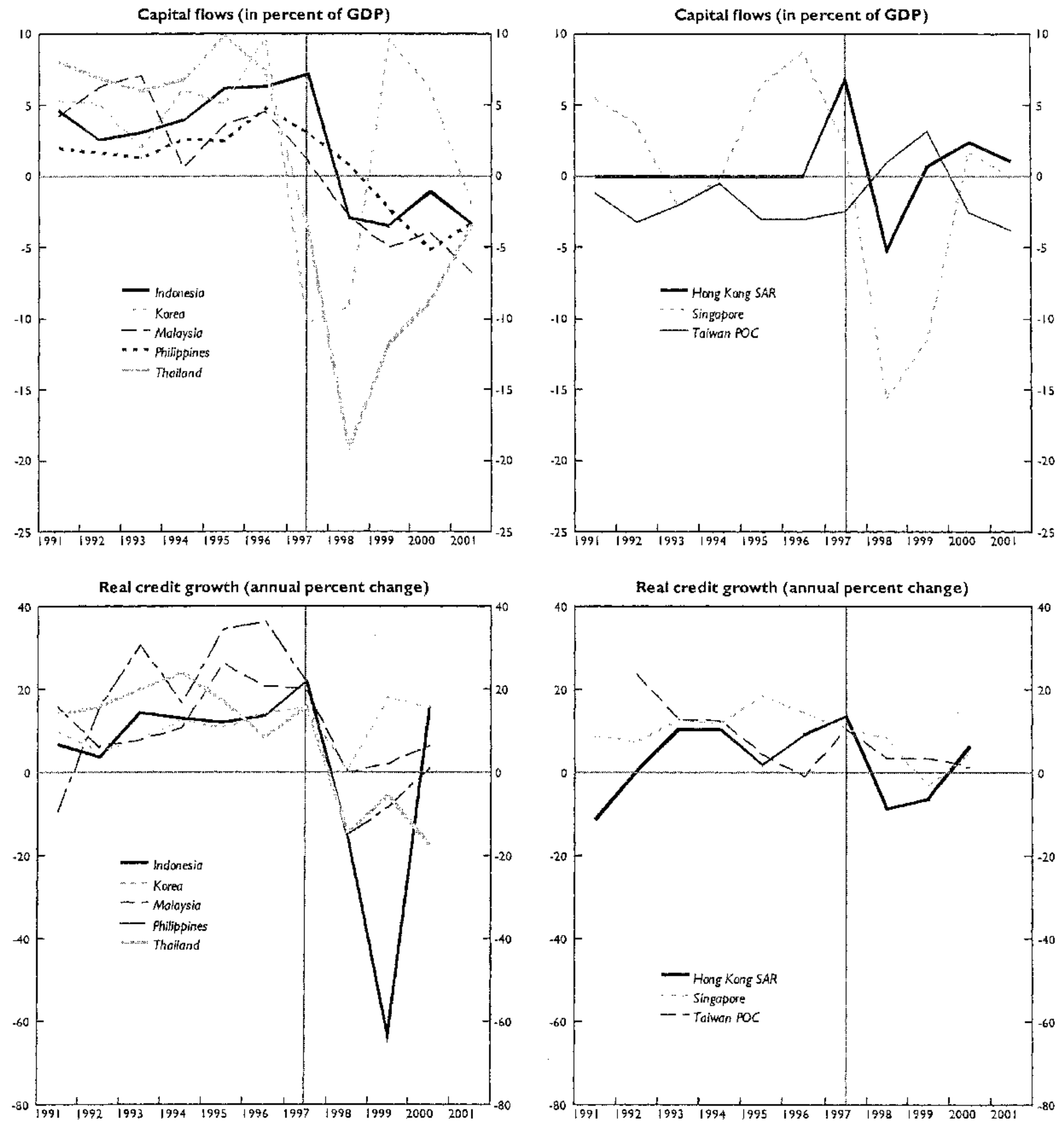

Source: IFS, APDCORE, World Economic Outlook and staff estimates. 
Figure 5. Selected Asian Countries: Real Credit and Real Property Returns (moving average of order 4)
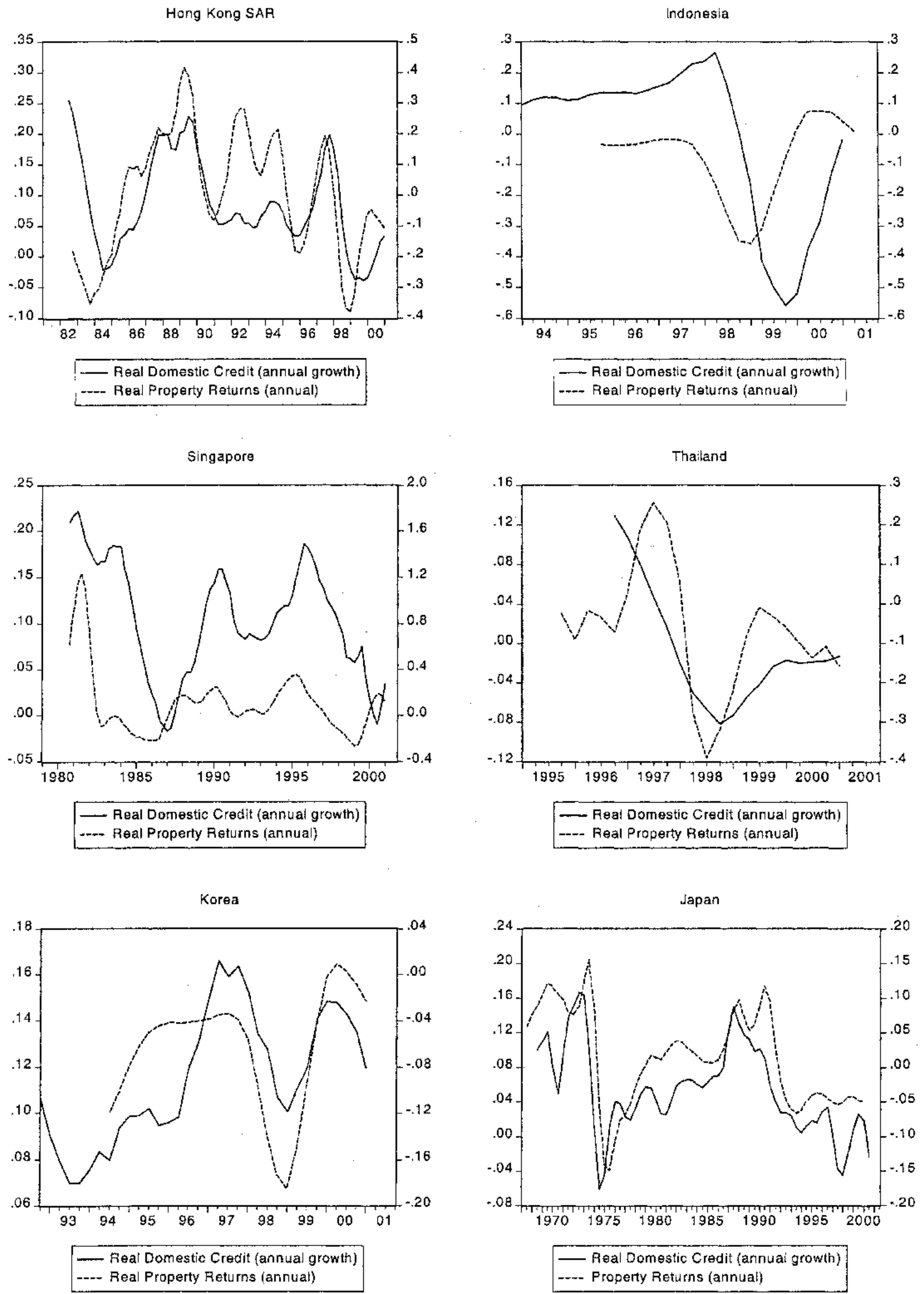
Figure 6. Selected Asian Countries: Real Credit to the Private Sector and Property Stock Returns (moving average of order 12)
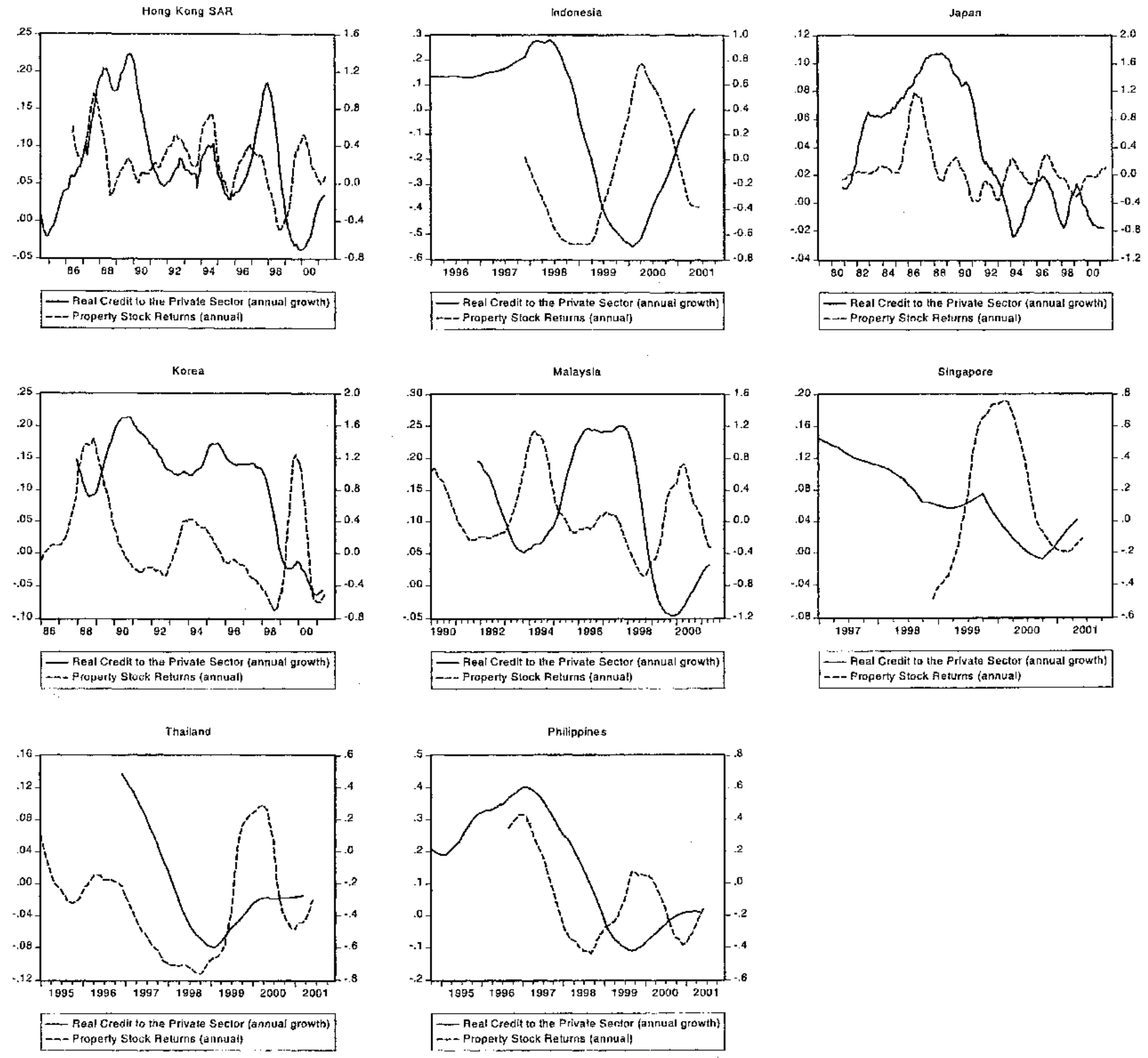
Figure 7. Selected Asian Countries: Real Credit to the Private Sector and Stock Relurns (moving average of order 12)
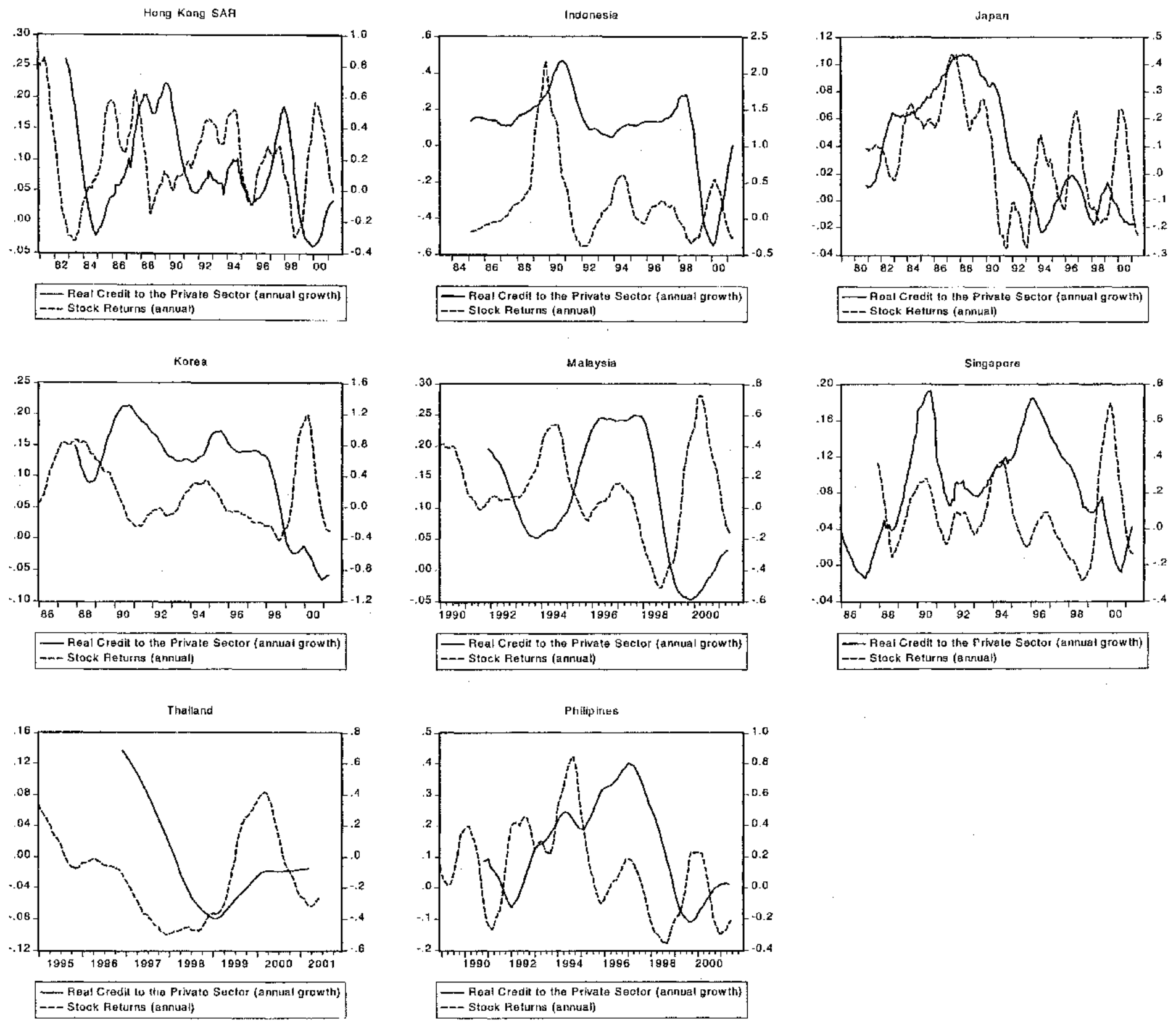
Figure 8

Selected Asian Countries: Stock Market Indices and Non-performing Loans
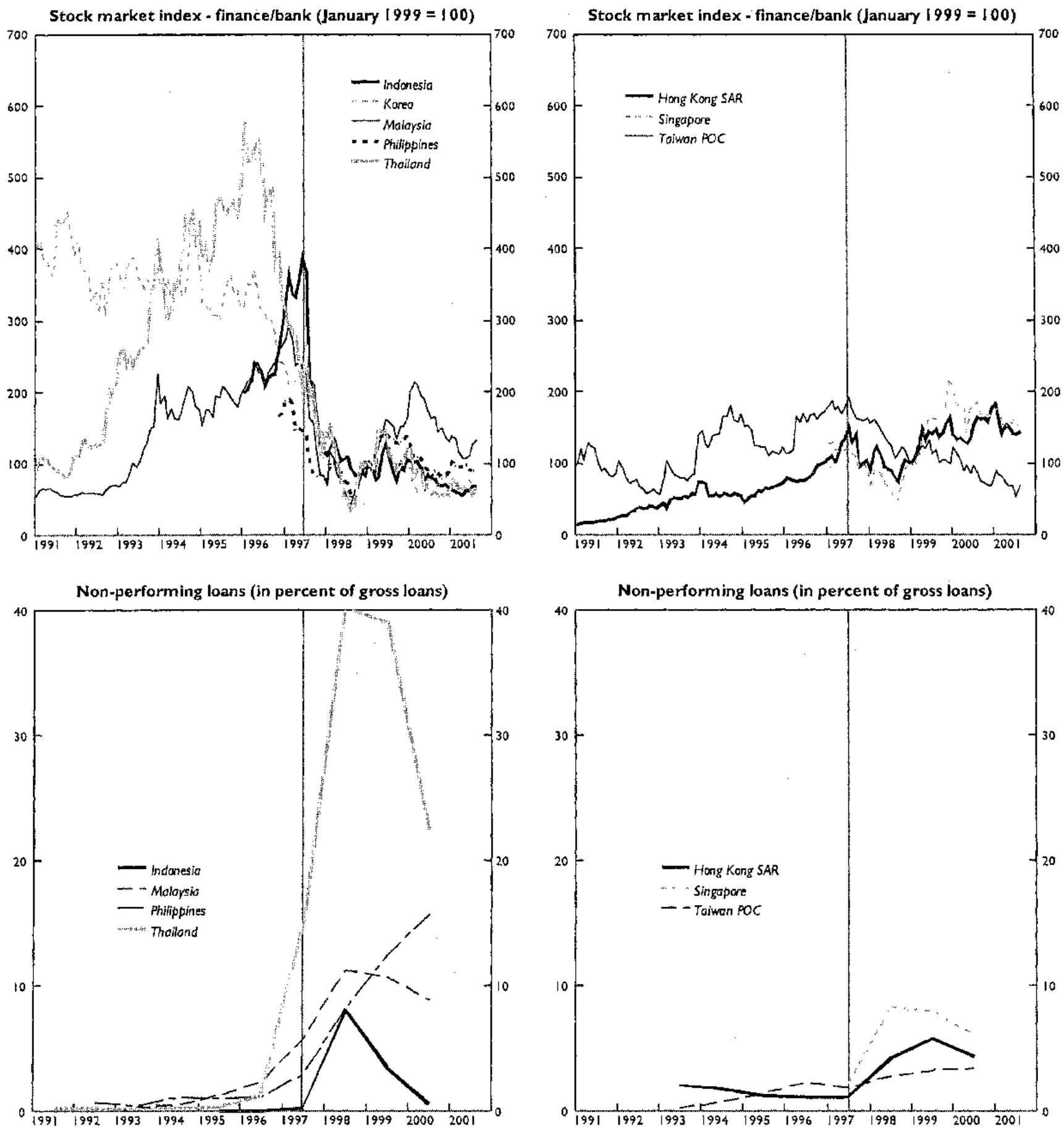

Source: Bankscope and CEIC. 
Figure 9

Selected Asian Countries: External Indicators

(End of period)
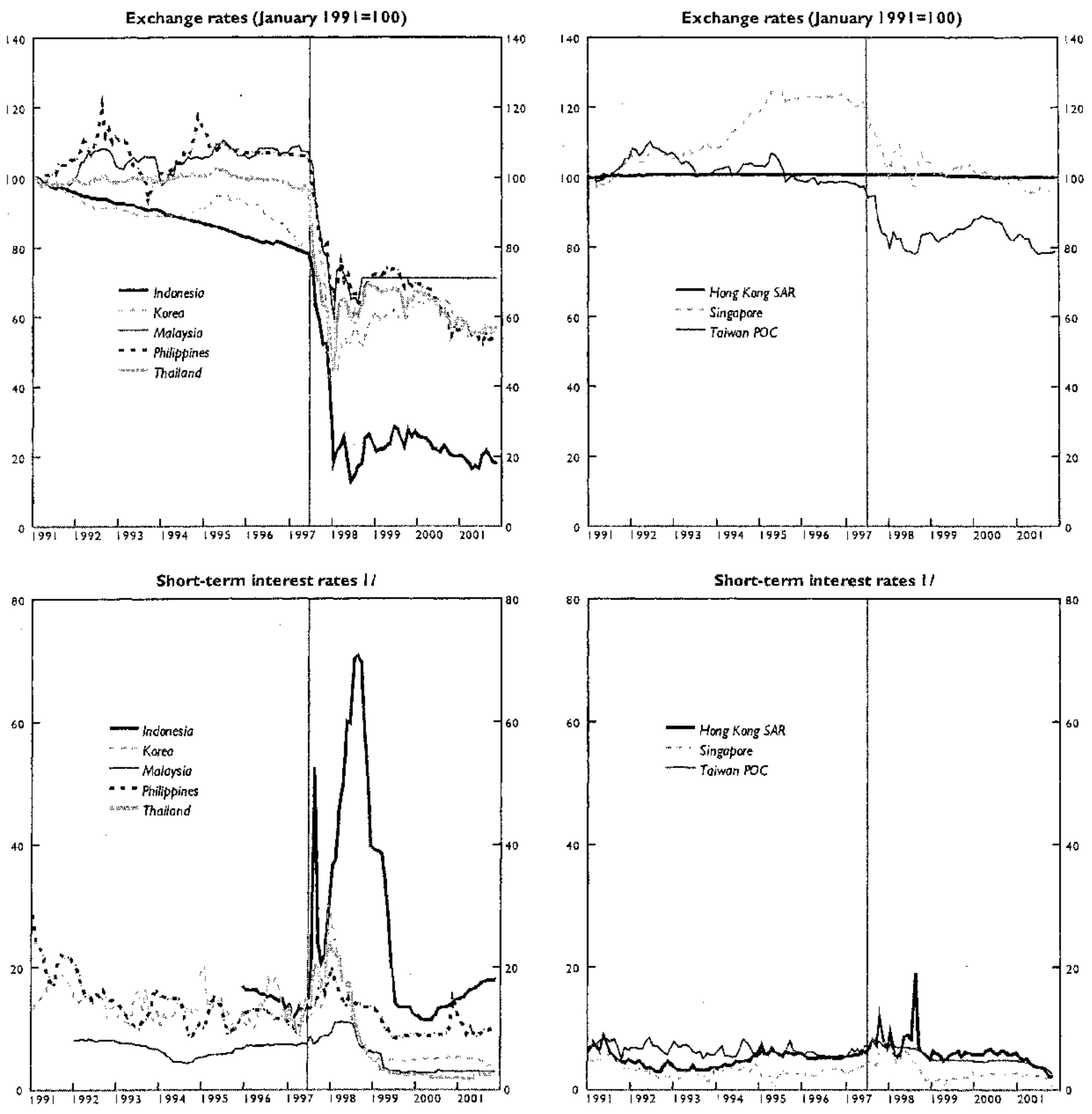

Source: APDCORE, CEIC, WEFA INTLINE.

I/ Hong Kong SAR, I-month HIBOR; Indonesia, I-montts JBOR; Korea, overnight call market rate;Malaysia, I-month KLIBOR; Philippines, 91 -day Treasury Bill Rate: Singapore, I-month SIBOR; Taiwan POC, overnight interbank; Thailand-I-month repo. 
Figure 10

Selected Asian Countries: External Indicators
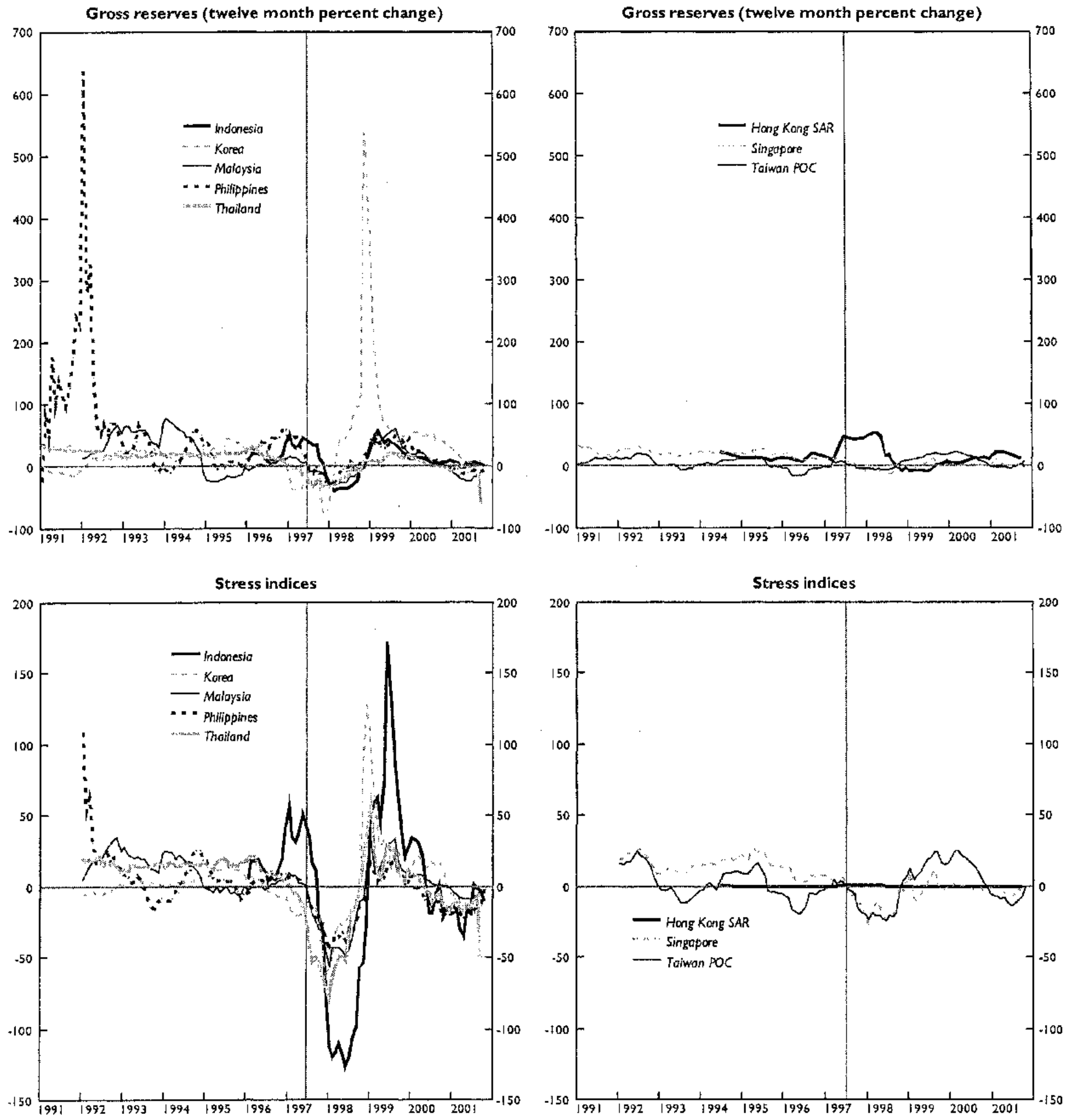

Source: IFS, APDCORE and staff estimates. 
Figure 11a. Impulse Response to One Standard Deviation (Cholesky Decomposition)

Hong Kong SAR

Response of $\mathrm{Cp}$ to shock from $\mathrm{Cp}$

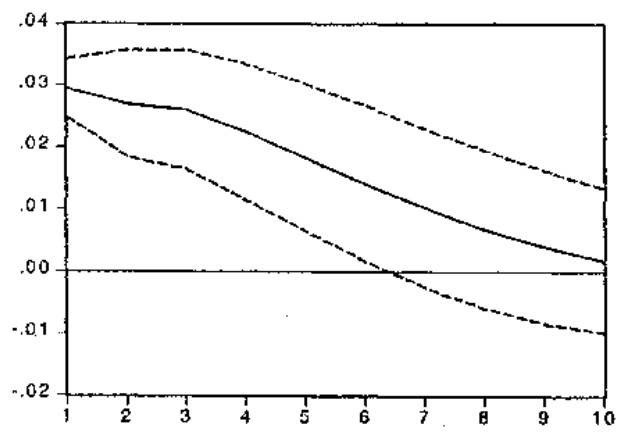

Response of PPI to Shock from $C P$

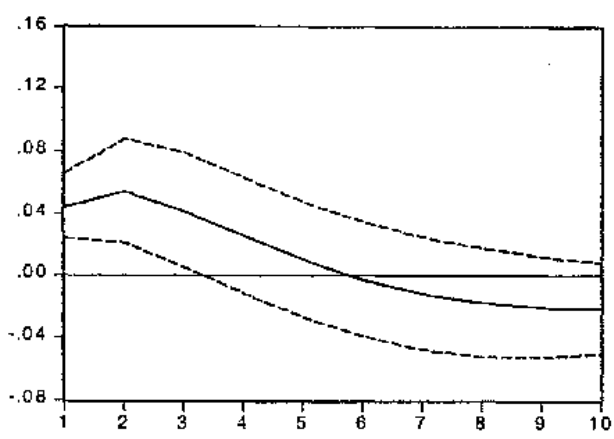

Hesponse of GDP to Shock irom $\mathrm{Cp}$

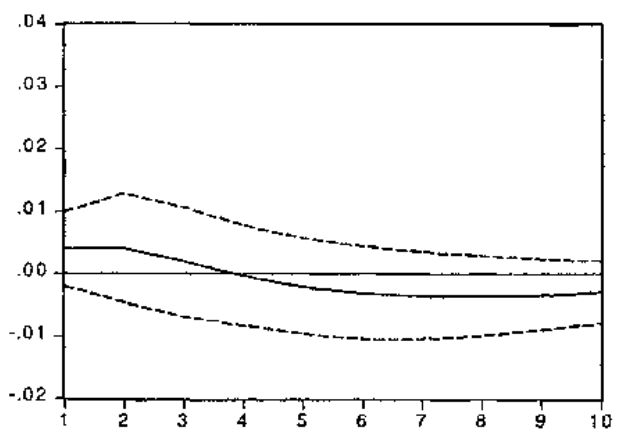

Response of $\mathrm{Cp}$ to Shock Irom PPi

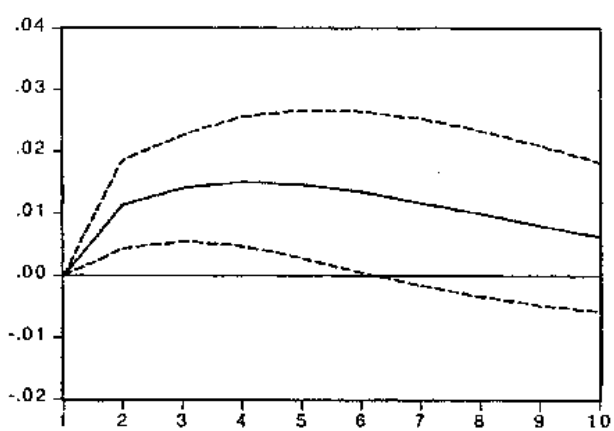

gesponse of PPI to Shock from PP

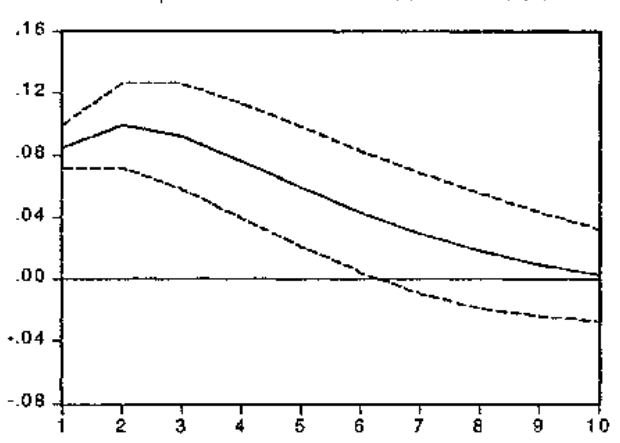

Response of GDP to Shock from PPi

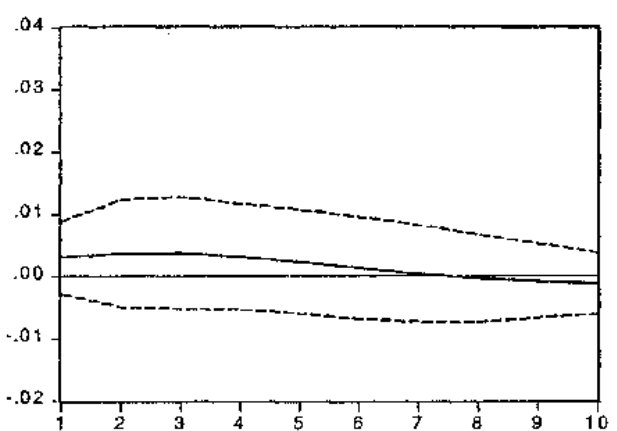

Response of $\mathrm{C} p$ to shock from GDP

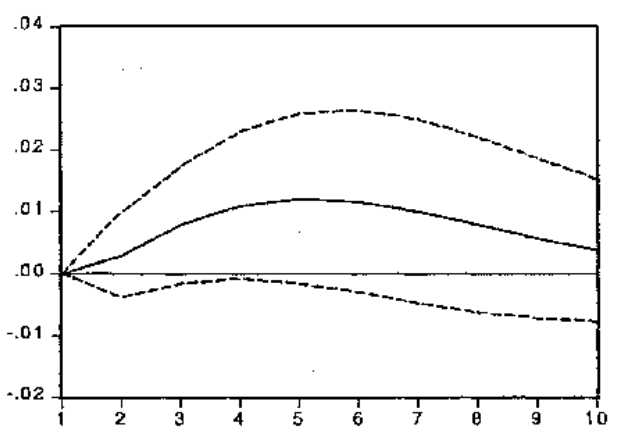

Response of PPI to Shock from GDP

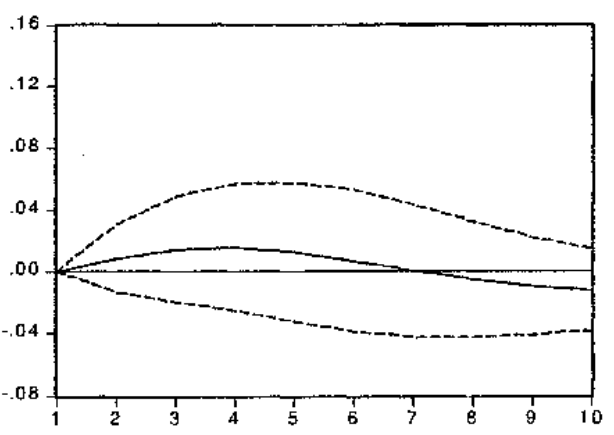

Response of GDP to Shock from GDP

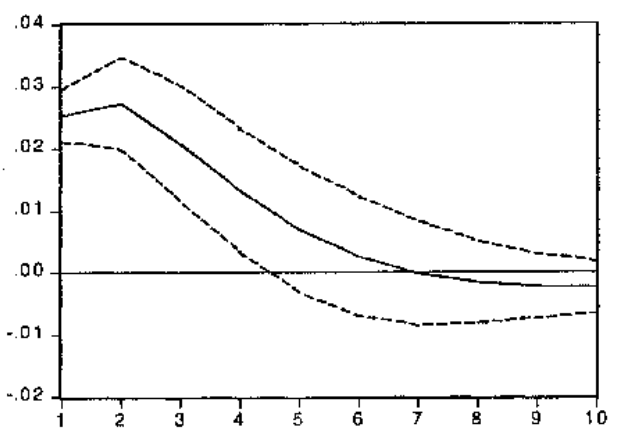



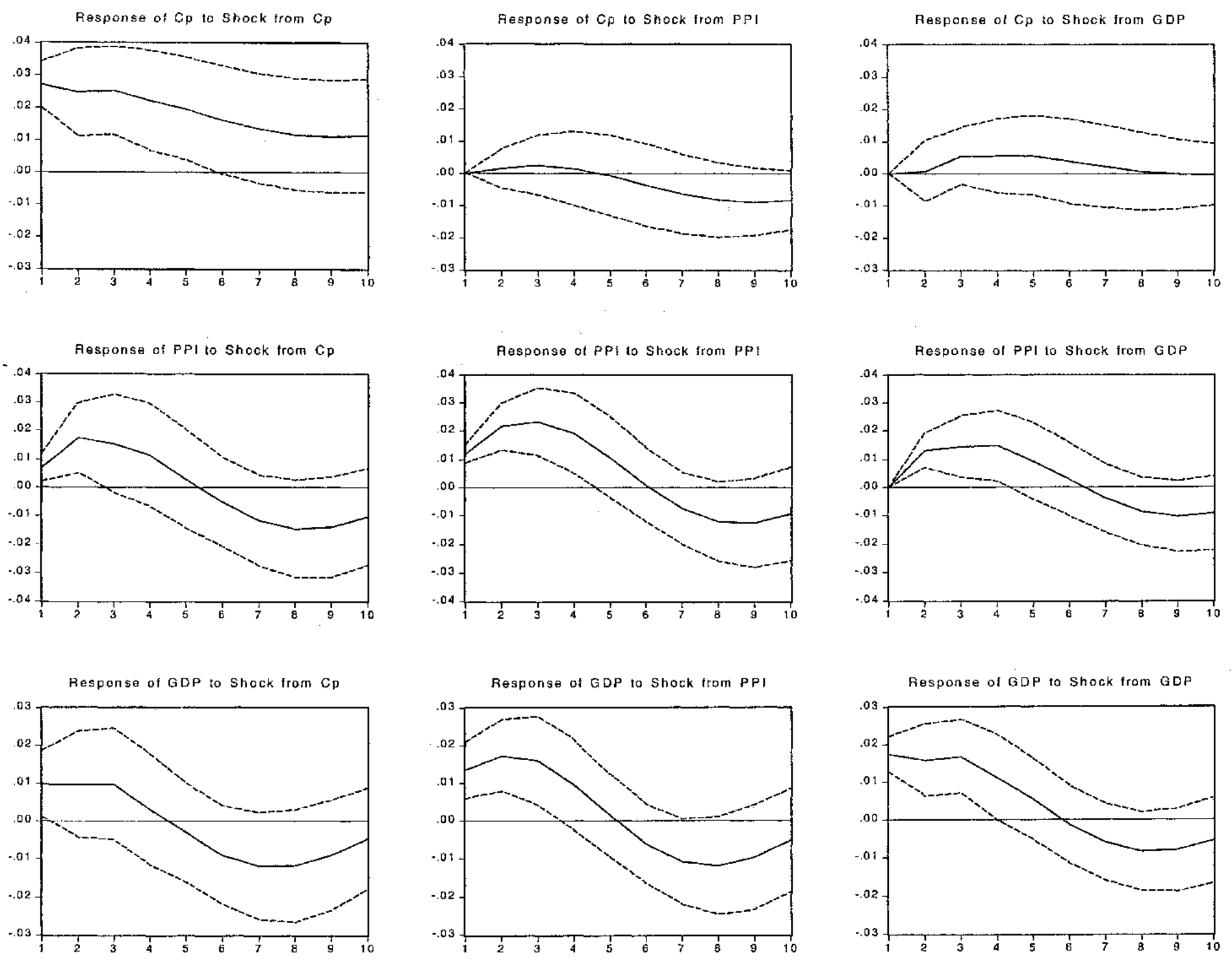
Figure 11c. Impulse Response to Cholesky One Standard Deviation Thailand
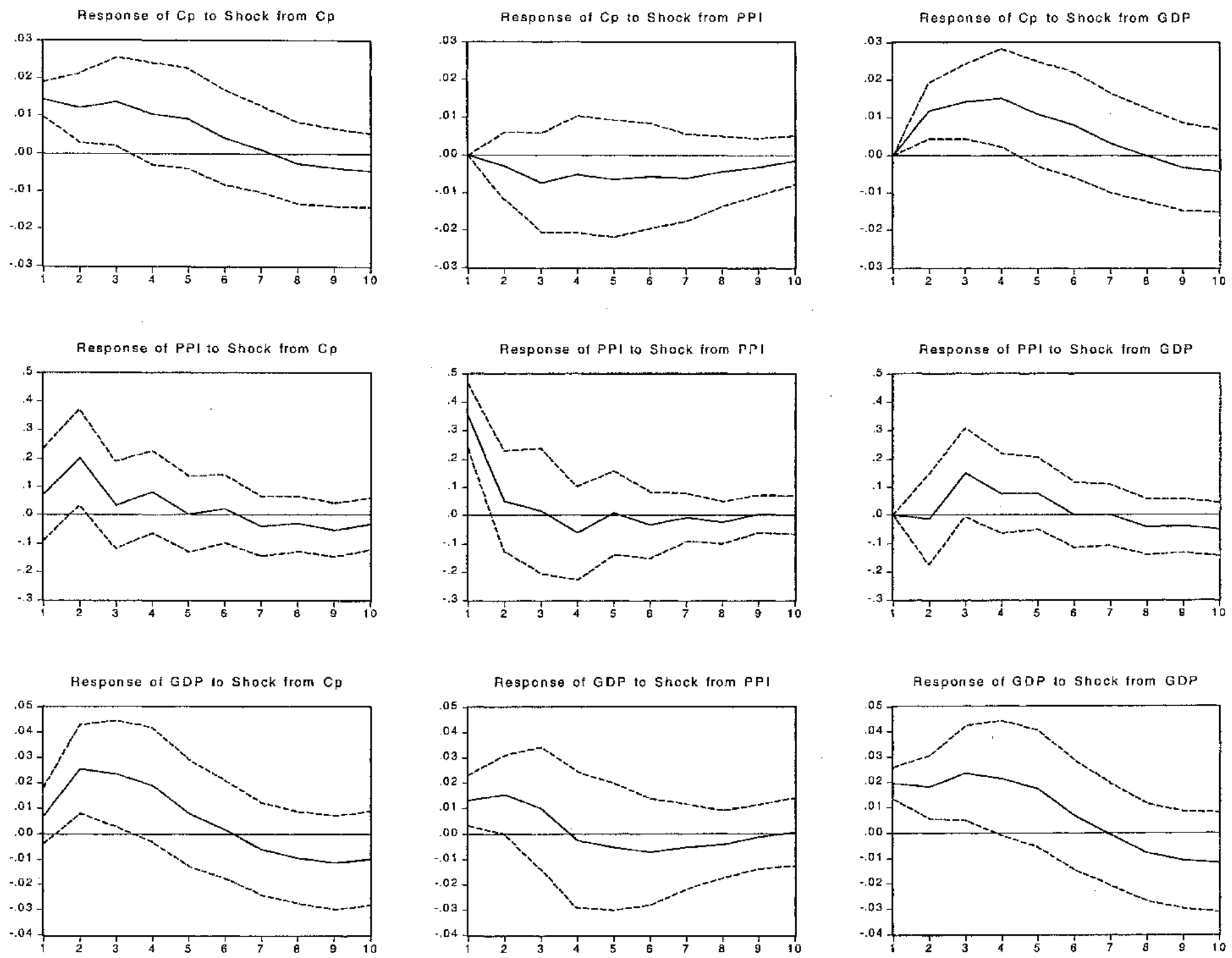

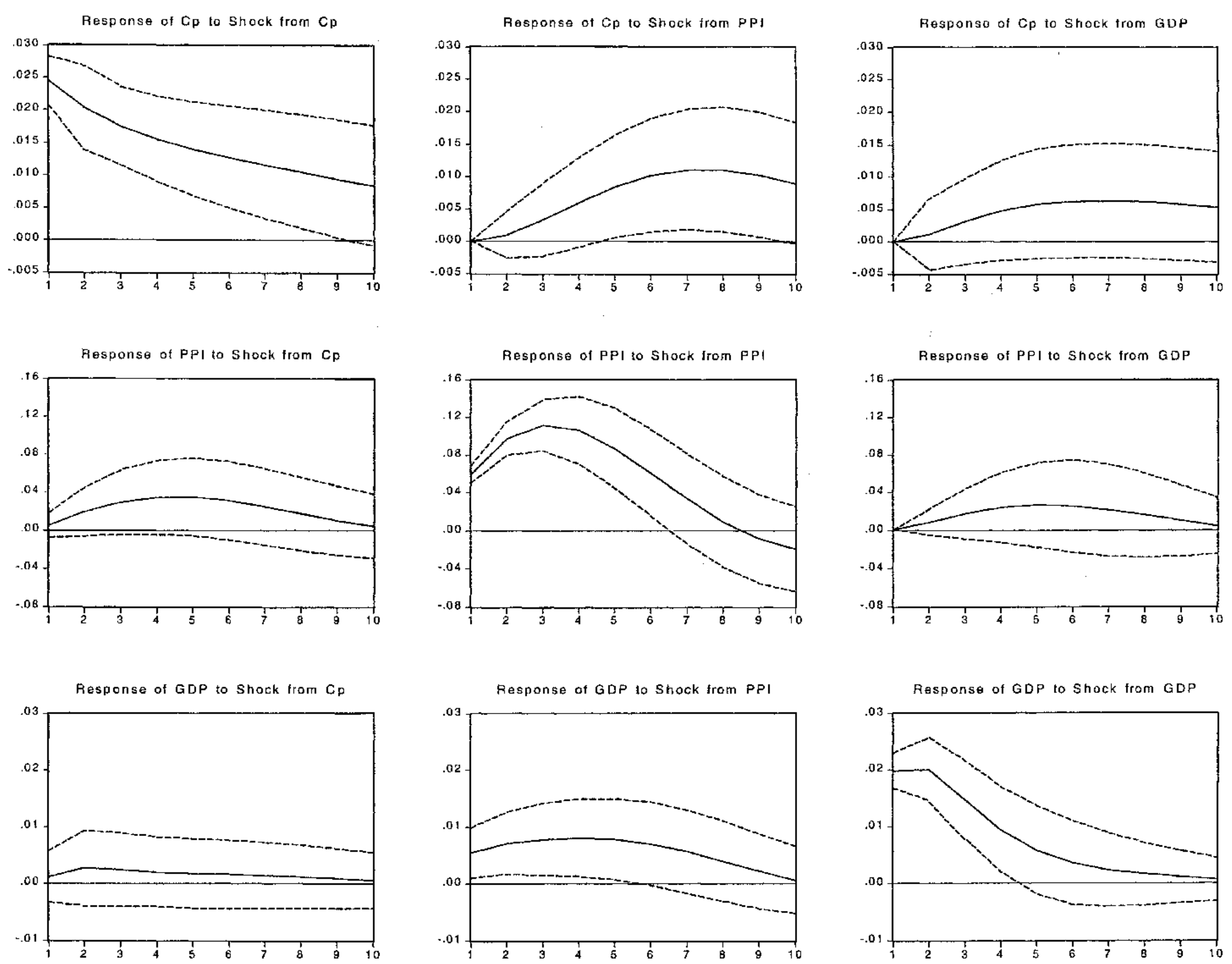
Figure 12. Selected Asian Countries: Property and Overall Stock Retums
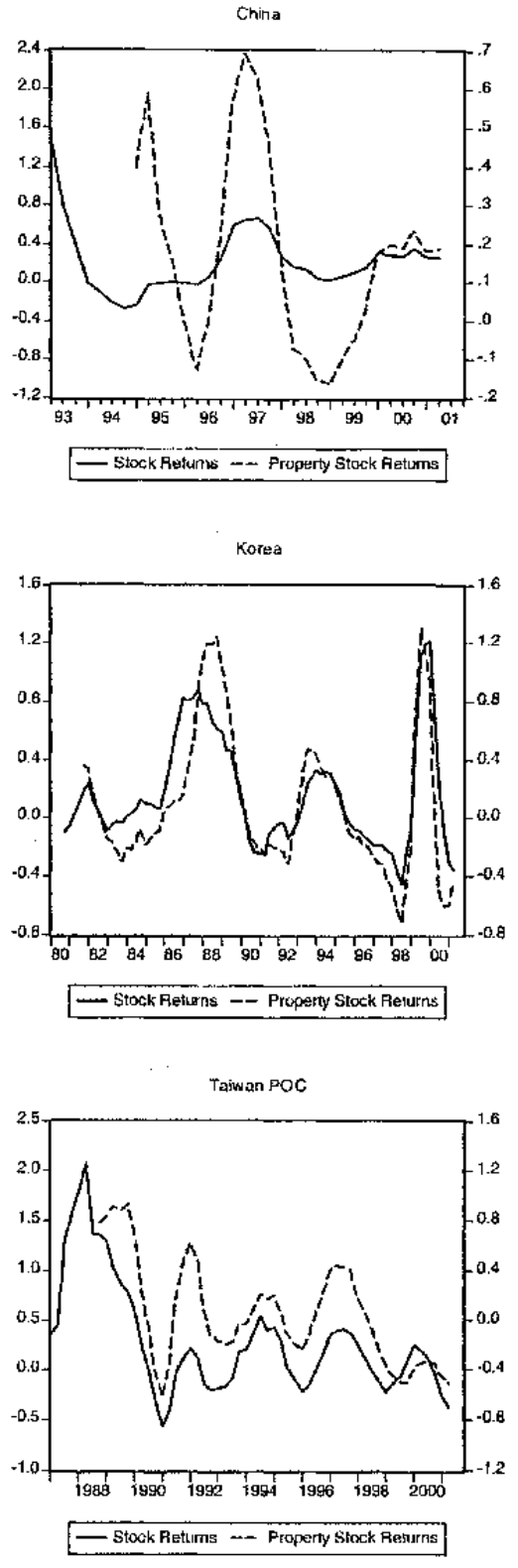
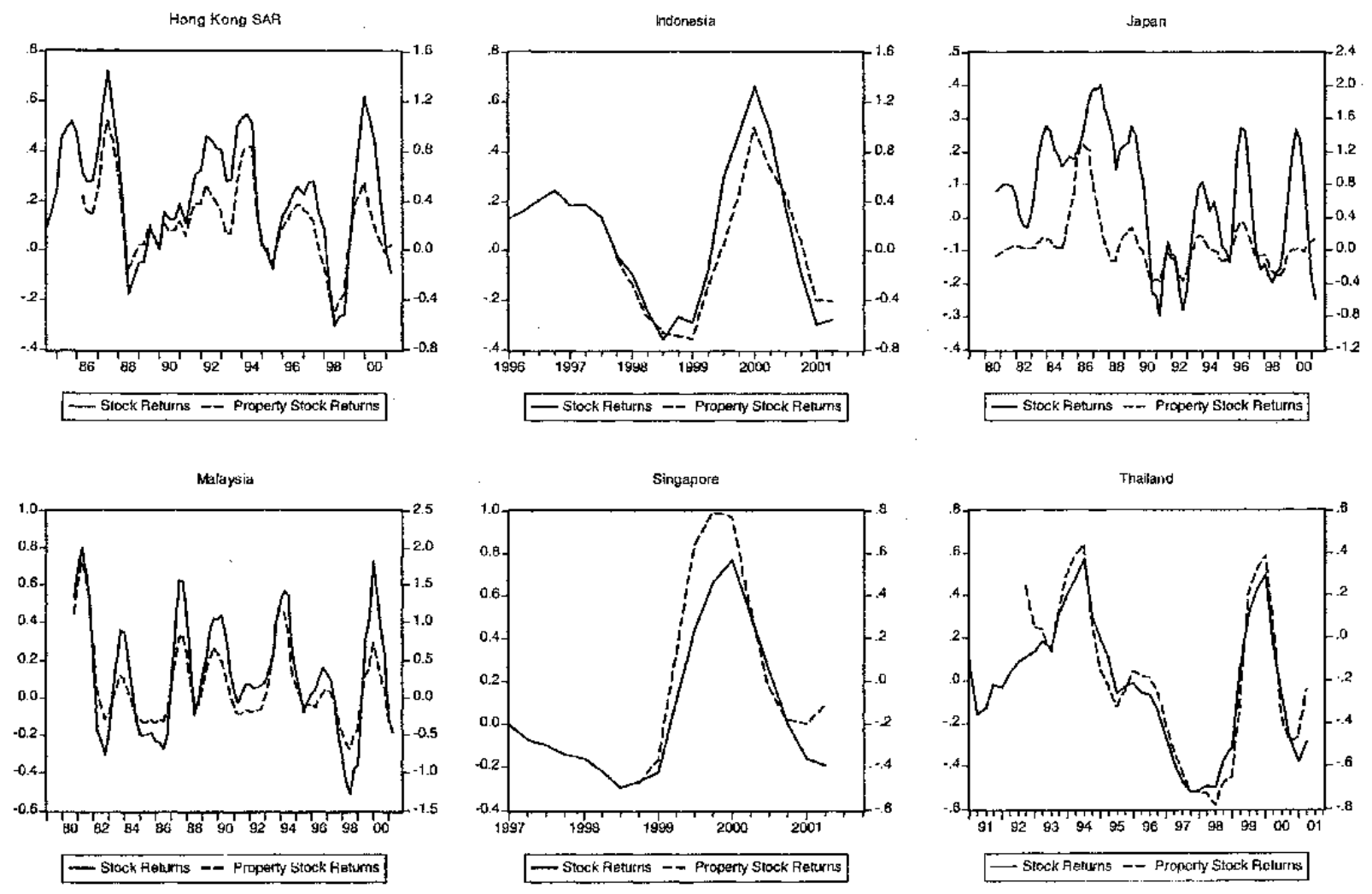

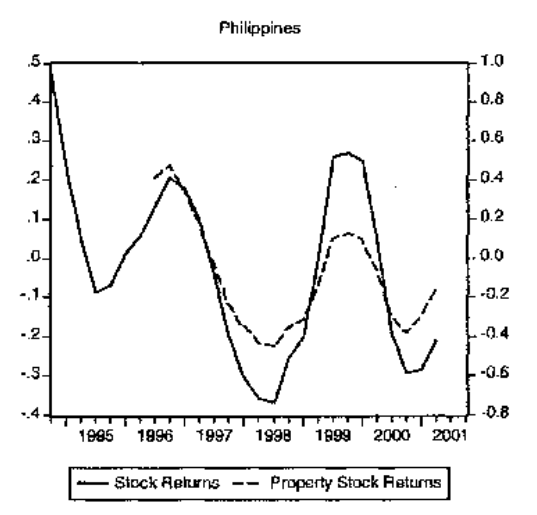


Figure 13. Selected Asian Countries: Twelve-Month Cortelation Between Property Stock Returns and Overall Stock Returns
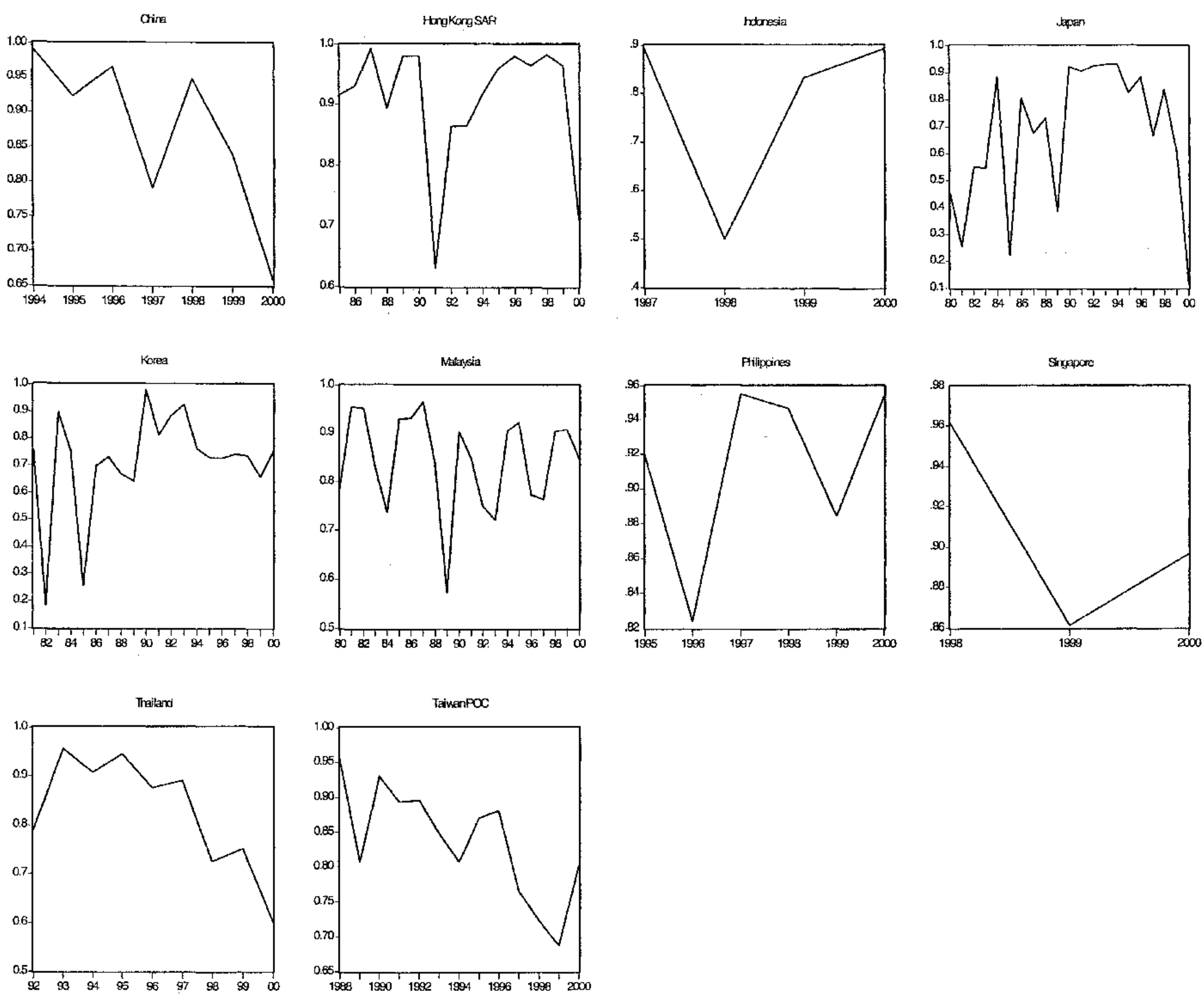


\section{APPENDIX 1: ASSUMPTIONS UNDERLYING TABLE 1}

Capital inflow surge: average inflow of private capital as percent of GDP over 1991-96 (x).

$$
\begin{cases}v^{\prime} \dot{ } & >4 \text { percent } \\ v^{v} & 2 \leq x \leq 4 \\ X & x<2\end{cases}
$$

Real credit growth: average annual percent change over 1991-96(x).

$$
\begin{cases}\sqrt{ } \mathfrak{} & >15 \text { percent } \\ \sqrt{ } & 5 \leq x \leq 15 \\ X & x<5\end{cases}
$$

Property price bubble: measured by both a decline in property price index $(x)$ and in property stock index $(y)$ from peak to trough during the Asian crisis

$$
\begin{cases}\sqrt{ } & x<-50 \text { percent or } y<-80 \text { percent } \\ \sqrt{ } & -50 \text { percent } \leq x \leq-30 \text { percent or }-80 \text { percent } \leq y \leq-50 \text { percent } \\ X & x>-30 \text { percent and } y>-50 \text { percent }\end{cases}
$$

Stock market bubble: measured by decline in composite stock market index $(\mathrm{x})$ during the Asian crisis

$$
\begin{cases}\sqrt{ } & x<-70 \text { percent } \\ \sqrt{ } & -70 \text { percent } \leq x \leq-40 \text { percent } \\ X & x>-40 \text { percent }\end{cases}
$$

Banking crisis: the severity of the crisis is qualitatively measured by various indicators

Severity of the crisis is measured by the following indicators: $\left\{\begin{array}{l}\text { systemic runs } \\ \text { multiple closure } \\ \text { high NPLs } \\ \text { under capitalized }\end{array}\right.$

Exchange rate crisis: measured by both a market pressure index $(\mathrm{x})$ defined in the data appendix and short-term interest rates (y) during the Asian crisis

$$
\begin{cases}V & x<-50 \text { percent or } y>30 \text { percent } \\ V & -50 \text { percent } \leq x \leq-30 \text { percent or } 20 \text { percent } \leq y \leq 30 \text { percent } \\ X & x>-30 \text { percent and } y<20 \text { percent }\end{cases}
$$




\begin{tabular}{|c|c|c|}
\hline Data Source for Property prices (PP) and Stock exchange (SE) data & SOURCE & TDENTIFER \\
\hline \multicolumn{3}{|l|}{ HONG KONG SAR } \\
\hline PP HK: Property Prices Index: Donnestic Premises & CEIC & HEOK \\
\hline PP HK: Property Price Index: Retail Premises & CEIC & HEOOB \\
\hline PP HK: (DC) Property Price Index (PPI): Donnstic Premises (uscd as proxy before 1997) & CEIC & HEAC \\
\hline PP HK: (DC) Propenty Price Index: Relail Premises (used as proxy before 1997) & CEIC & $\mathrm{HEAD}$ \\
\hline SE HK: Indcx: Hang Seng & CEIC & $\mathrm{HZJA}$ \\
\hline SE YKK: Index: Hang Seng Properties & CEIC & HZID \\
\hline SE LIK: Index: Hang Scng Finance & CEIC & HZIB \\
\hline SE HK: l'E Ratio: HKSE: All Stocks & CEIC & HZBA \\
\hline SE IIK: PE Ratio: HKSE: Finance Sector & CEIC & HZBB \\
\hline SE IIK: PE Ratio: HKSE: Propertics Sector & CEIC & $\mathrm{HZBD}$ \\
\hline \multicolumn{3}{|l|}{ INDONESIA } \\
\hline PP ID: Residential Property Price Irdex: BI: $9 y=100$ & CEIC & DEFEA \\
\hline SE ID: JSX: Index: Jakarta Compusite Index & CEIC & DZEA \\
\hline SE ID: JSX: Index: Propcty & CEIC & $\mathrm{DZED}$ \\
\hline SE ID: ISX: Index: Finarce & CEIC & DZEE \\
\hline SE ID: ISX: PE Ratio: Avcrage & CEIC & DZBB \\
\hline SE ID: ISX: PE Rativ: Construction, Property and Real Estates & CEIC & DZBH \\
\hline SE ID: ISX: PE Ratio: Finance: Bank & CEIC & DZBJA \\
\hline \multicolumn{3}{|l|}{ KOREA } \\
\hline PP KR: Official Land Price Fluctucation Ratc: Whole Country & CEIC & KEPA \\
\hline PP KR: Official Land Price Fluctucation Ratc: Scoul & CEIC & KEPAD \\
\hline SE KR: Index: KSE KOSPI & $\mathrm{CEIC}$ & KZEA \\
\hline SE KR: Index: KSE General Construction & $\mathrm{CEIC}$ & KZES \\
\hline SE KR: Index: KSE Financiad Institutions: Banks & $\mathrm{CEIC}$ & KZEVA \\
\hline SE KR: PE Katio: KSE: Mth Ayg: Arith: All Companics & CEIC & $\mathrm{KZDB}$ \\
\hline SE KR: PE Ratio: KSE: Mth End: Arith: Financial Instiutions & CEIC & KZDBV \\
\hline \multicolumn{3}{|l|}{ MALAYSIA } \\
\hline PP MY: House Price Index & CEIC & MERF \\
\hline pP MY: House Price Index: Kuala Lumpur & CEIC & MERFEA \\
\hline SE MY: KLSE: Index: Conyrasire & CEIC & MZEB \\
\hline SE MY: KLSE: Index: Property & CEIC & MZED \\
\hline SE MY: KLSE: Index: Finance & CEIC & $M Z E L$ \\
\hline SE MY: KLSE: PE: Main Board All Sharc Index & CEIC & $\mathrm{MZBC}$ \\
\hline SE $\quad$ MY: KLSE: PE: Finance Index & CFIC & MZBI \\
\hline SE MY: KLSE: PE: Propcrty Index & CEIC & MZZBJ \\
\hline \multicolumn{3}{|l|}{ PHILIPPINES } \\
\hline SE PH: Index: PSE Composite Index & CEIC & PZIA \\
\hline SE PH: Index: PSE Property Index & CEIC & PZIE \\
\hline SE PH: Index: PSE Banking and Financial Services & CEIC & PZIF \\
\hline SE PH: PE Ratio: PSE: Total & CEIC & PZBA \\
\hline SE PH: PE Ratio: PSE: Property & $\mathrm{CPIC}$ & PZBAC \\
\hline SE PH: PE Ratio: PSE: Banking & CEIC & PZBAD \\
\hline \multicolumn{3}{|l|}{ SIGAPORE } \\
\hline PP SG: PPI: Private Residential: All & CEIC & SEVA \\
\hline PP SG: PPI: Office Space: All & CEIC & SEVB \\
\hline SE SG: Index: SES All Share & CEIC & SZIB \\
\hline SE SG: Index: SES Properties & CEIC & SZIPG \\
\hline SE SG: Indcx: SES Finamce Index & CEIC & SZIPE \\
\hline SE SG: SES: PE Ratio: Total & CEIC & SZCA \\
\hline SE SG: SES: PE Ratio: Properties & CEIC & SZCAP \\
\hline SE SG: SES: PE Ratio: Finance & CEIC: & SZCAN \\
\hline \multicolumn{3}{|l|}{ TAIWAN POC } \\
\hline PP TW: Urban Land Price Index: General: Taiwan and Fuchien Area & CEIC & WEFAA \\
\hline PP TW: Urban Land Price Index: Residential: Taiwan and Fuchicn Arca & CEIC & WEFBA \\
\hline PP TW: Urban Land Price Index: Commercial: Taiwarı and Fuchien Area & CEIC & WEFCA \\
\hline SE TW: Index: TSE: Capitalization Weighted Stock & CEIC & WZJA \\
\hline SE TW: Index: TSE: Consiruction & CEIC & WZIG \\
\hline SE. TW: Index: TSE: Finance & CEIC & WZJH \\
\hline SE TW: TSE: PE Ratio: All Listed Stocks & CEIC & WZBA \\
\hline SE TW: TSE: PE Ratio: Construktion & CEIC & WZBO \\
\hline SE $\quad$ TW: TSE: PE Ratio: Finance & CEIC & WZBP \\
\hline \multicolumn{3}{|l|}{ THAILAND } \\
\hline PP TH: l'rice of Housing Offered for Sale: Detached House: Arithmatic Mean & CEIC & TEPAAA \\
\hline PP TH: Price of Housing Offered for Salc: Comnercial Bldg: Arithmatic Mean & CEIC & TEPAGA \\
\hline PP TH: Constuction Price Index & CEIC & TEVA \\
\hline PP Grade A office & DESK & \\
\hline Pp High class residerijal condoninium & DESK & \\
\hline SE. TH: Index: SET & CEIC & TZIA \\
\hline
\end{tabular}




\section{REFERENCES}

Allen, Franklin, and Douglas Gale, 2000, "Bubbles and Crises," The Economic Journal, Vol. 110, No.1, 236-55.

Bank for International Settlement, Annual Report, June 2001, Chapter VII.

Berg, Andrew, 1999, “The Asia Crisis: Causes, Policy Response, and Outcomes," IMF Working Paper No. 99/132, (Washington: International Monetary Fund).

Bernanke, Ben, 1983, "Nonmonetary Effects of the Financial Crisis in the Propagation of the Great Depression," American Economic Review, Vol. 73, 257-76.

Bernanke, Ben, and Mark Gertler, 1995, "Inside of a Black Box: The Credit Channel of monetary policy Transmission," Journal of Economic Perspectives, Vol. 9, No. 4, 27-48.

Corsetti, Giancarlo, Paolo Pesenti, and Nouriel Roubini, 1998, "What Caused the Asian Currency and Financial Crisis? Part I: A Macroeconomic Overview," mimeo, 1-39.

Dekle, Robert, and Kenneth Kletzer, 2001, "Domestic Bank Regulation and Financial Crises: Theory and Empirical Evidence from East Asia," IMF Working Paper No. 01/63, (Washington: International Monetary Fund).

Herring, Richard, and Susan Wachter, 1999, "Real Estate Booms and Banking Busts--An International Perspective," Group of Thirty, Occasional Paper No. 58, Washington, D.C.

Horiguchi, Yusuki, 2001, "Should External Borrowing Be Restrained?" mimeo, International Monetary Fund.

Hilbers, Paul, Qin Lei and Lisbeth Zacho, 2001, "Real Estate Market Developments and Financial Sector Soundness," IMF Working Paper No. 01/129, (Washington: International Monetary Fund).

International Monetary Fund, December 1997, World Economic Outlook, (Washington: International Monetary Fund), Chapter III..

International Monetary Fund, May 2000, World Economic Outlook, (Washington: International Monetary Fund), Chapter III..

Kalra, Sanjay, Dubravko Mihaljek, and Christoph Duenwald, 2000, "Property Prices and Speculative Bubbles: Evidence from Hong Kong SAR, IMF Working Paper No. 00/2, (Washington: International Monetary Fund). 
Kaminski, Graciela, and Carmen Reinhart, 1999, "The Twin Crises: The Causes of Banking and Balance-of-Payments Problems," American Economic Review, Vol. 89, No. 3, 473-500.

Kiyotaki, Nobuhiro, and John Moore, 1997, "Credit Cycles," Journal of Political Economy, Vol. 105, On. 2, $211-48$.

Kochhar, Kalpana, Prakash Lougani, and Mark Stone, 1998, "The East Asian Crisis: Macroeconomic Developments and Policy Lessons," IMF Working Paper No. 98/128, (Washington: International Monetary Fund)

Krueger, Anne, 2000, "Conflicting Demands on the International Monetary Fund," American Economic Review, Vol. 90, No. 2, 38-42.

Krugman, Paul, 1998, "What Happened to Asia," mimeo.

Lane, Thimothy, Atish Ghosh, Javier Hamann, Steven Phillips, Marianne, Schultze-Ghattas, Tsisi Tsikata, 1999, "IMF-Supported Programs in Indonesia, Korea, and Thailand," IMF Occasional Paper No. 178, (Washington: International Monetary Fund).

Meesook, Kanita, Il Houng Lee, Olin Liu, Yougesh Khatri, Natalia Tamirisa, Michael Moore, and Mark Krysl, 2001, "Malaysia: From Crisis to Recovery," IMF Occasional Paper No. 178, (Washington: International Monetary Fund)

Ministry of Trade and Industry, Republic of Singapore, 2001, "Residential Property Prices and National Income," Economic Survey of Singapore, First Quarter, 49-51.

Mishkin, Frederic, 1996, "Understanding Financial Crisis: A developing Country Perspective,"NBER Working Paper No. 5600, (Cambridge: National Bureau of Economic Research). 